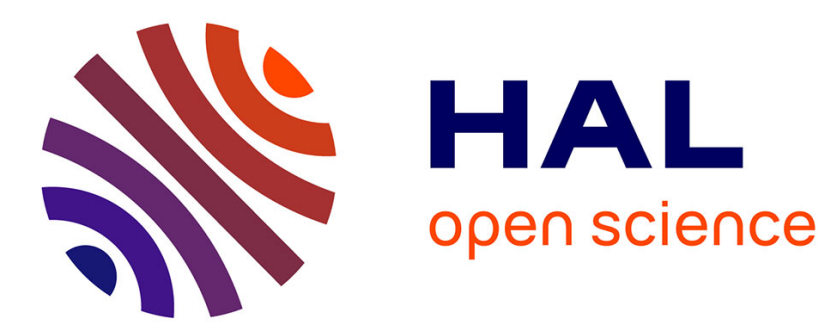

\title{
Increasing chemical weathering in the Himalayan system since the Last Glacial Maximum
}

Maarten Lupker, Christian France-Lanord, Valier Galy, Jérôme Lavé, Hermann Kudrass

\section{- To cite this version:}

Maarten Lupker, Christian France-Lanord, Valier Galy, Jérôme Lavé, Hermann Kudrass. Increasing chemical weathering in the Himalayan system since the Last Glacial Maximum. Earth and Planetary Science Letters, 2013, 365, pp.243 - 252. 10.1016/j.epsl.2013.01.038 . hal-01763489

\section{HAL Id: hal-01763489 \\ https://hal.univ-lorraine.fr/hal-01763489}

Submitted on 19 Nov 2019

HAL is a multi-disciplinary open access archive for the deposit and dissemination of scientific research documents, whether they are published or not. The documents may come from teaching and research institutions in France or abroad, or from public or private research centers.
L'archive ouverte pluridisciplinaire HAL, est destinée au dépôt et à la diffusion de documents scientifiques de niveau recherche, publiés ou non, émanant des établissements d'enseignement et de recherche français ou étrangers, des laboratoires publics ou privés. 


\title{
Increasing chemical weathering in the Himalayan system since the Last Glacial Maximum
}

\author{
Maarten LUPKER ${ }^{1}$, Christian FRANCE-LANORD ${ }^{1}$, Valier GALY', Jérôme LAVE' ${ }^{1}$, \\ Hermann KUDRASS $S^{3}$
}

${ }^{1}$ Centre de Recherches Pétrographiques et Géochimiques (CRPG), UMR 7358, CNRSUniversité de Lorraine, 15 rue Notre Dame des Pauvres, 54501 Vandoeuvre les Nancy, Cedex, France.

${ }^{2}$ Woods Hole Oceanographic Institution (WHOI) - Department of Marine Chemistry and Geochemistry, 360 Woods Hole Rd., Woods Hole, MA 02543, USA.

${ }^{3}$ MARUM zentrum für Marine Umweltwissenschaften, Bremen, Germany.

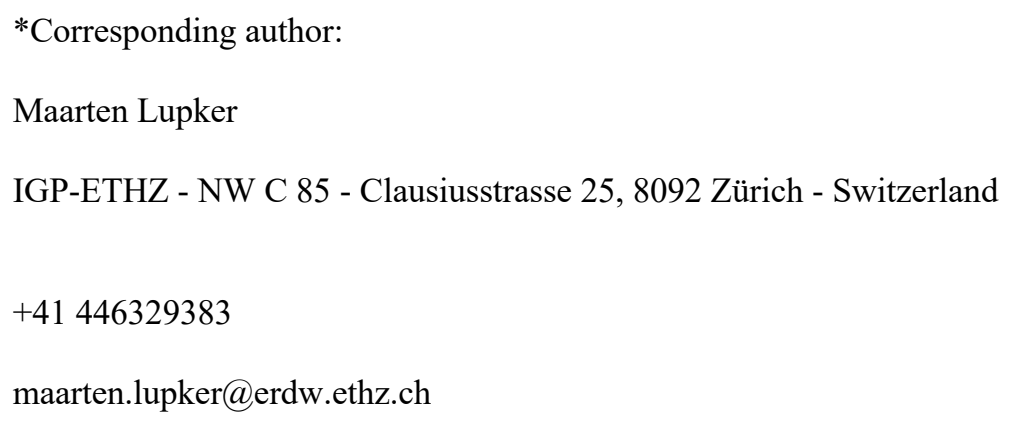


ABSTRACT:

Continental chemical weathering is central in Earth's surface biogeochemical

3 cycles as it redistributes elements across reservoirs such as the crust and the oceans.

4 However the evolution of weathering through time and its response to external forcing

5 such as changes in climate remain poorly constrained. In this work, a composite

6 sediment record from the Bay of Bengal is used to document the evolution of chemical

7 weathering in the Himalayan system (Himalayan range and Indo-Gangetic floodplain),

8 the world largest sediment conveyor to the oceans, since the Last Glacial Maximum

9 (LGM). The degree of weathering of the sediments is documented using mobile to

10 immobile ratios such as $\mathrm{K} / \mathrm{Si}$ and $\mathrm{H}_{2} \mathrm{O}^{+} / \mathrm{Si}$ as well as detrital calcite abundance. Robust

11 weathering proxies are derived by correcting the chemical composition of sediment for

12 sorting effects that occur during transport and deposition. The Bay of Bengal record is

13 also further compared to the chemical composition of modern river sediments from the

14 Ganga \& Brahmaputra basin. Weathering proxies all indicate that the sediments

15 exported by the Ganga \& Brahmaputra Rivers became increasingly weathered over the

16 past $\sim 21 \mathrm{kyr}$, whereas, $\mathrm{Sr}$, Nd and major elements suggest a constant sediment

17 provenance in the system over the last $21 \mathrm{kyr}$. These changes in the degree of weathering

18 of the sediments show that the weathering flux exported by the system to the Indian

19 Ocean during the LGM was significantly lower than at present and demonstrate that

20 chemical weathering in continental scale basins such as the Ganga \& Brahmaputra

21 responds to Late Quaternary climate changes. 


\section{Introduction:}

Chemical weathering of continental rocks is the main source of soluble elements to the

25 oceans and therefore exerts a first order control on oceanic bio-geochemical cycles. Over

26 geologic time scales, silicate weathering and subsequent carbonate precipitation also draws

27 down atmospheric $\mathrm{CO}_{2}$ thereby stabilizing the earth's climate (Walker et al., 1981).

28 Continental weathering fluxes are a function of continent lithology, tectonic activity and

29 climate but the mechanisms and feedbacks linking silicate weathering to the earth's climate

30 remain debated (France-Lanord and Derry, 1997; Willenbring and von Blanckenburg, 2011).

31 A better understanding of these complex climate-weathering couplings can be gained by

32 studying the response of continents to climatic transitions in the past.

33 The role of the Himalayan orogeny in the long-term forcing of oceanic cycles and the

34 global climate has retained much attention (France-Lanord and Derry, 1997; Raymo et al.,

35 1988). However, the temporal variability of and controls on the evolution of weathering

36 fluxes exported by large basins remains poorly constrained and is often difficult to reconstruct

37 (Limmer et al., 2012). In particular, direct characterization of the response of chemical

38 weathering to abrupt climate perturbations has heretofore remained a challenge. We present a

39 record of chemical weathering intensity in the Himalayan system since the LGM. The

40 Himalayan system is defined here as the Himalayan range and the downstream Indo-Gangetic

41 floodplain drained by Ganga and Brahmaputra Rivers. No major change in tectonic forcing of

42 the Himalayan orogeny has been documented so far over the last glacial-interglacial period,

43 which enables us to discuss variations in sediment weathering as a response to climate 44 change.

\section{Setting and methods:}


The central part of the Himalayan range is drained by two major rivers, the Ganga and

49 Brahmaputra (Figure 1). Currently, the Ganga \& Brahmaputra transfers ca. $1.10^{9}$ Mt of

50 sediments to the Bay of Bengal, of which $90 \%$ is transported during the monsoon (RSP,

51 1996). River sediments were sampled mainly during monsoon seasons, in 2002, 2004, 2005 ,

52 2007, 2008 and 2010 across the Indo-Gangetic floodplain. Sampling locations mainly

53 included the front of the Himalayan range for the main trans-Himalayan Rivers of the Ganga

$54 \&$ Brahmaputra system, the outlet of the Ganga and the Brahmaputra as well as their

55 confluence - the lower Meghna - which integrates the entire sediment load exported from the

56 Ganga \& Brahmaputra basin (Figure 1). When possible, sediments were sampled along

57 vertical depth profiles through the water column in order to capture the full variability of the

58 sediment load. These profiles were complemented by bedload samples dredged from the

59 active channel of the rivers and freshly exposed bar sediments. Details on the sampling

60 procedure are described in Lupker et al. (2011).

61 Sediment cores were retrieved during RV Sonne cruise SO93 in 1994 from the shelf

$62(105 \mathrm{KL}$ and $107 \mathrm{KL})$ and the active channel levee system of the middle fan $(117 \mathrm{KL}, 118 \mathrm{KL}$

63 and 120KL) (Ittekkot et al., 2003). The chronology of the cores is provided by re-calibrated

64 (Reimer et al., 2009) ${ }^{14} \mathrm{C}$ ages on planktonic foraminifers (Weber et al., 1997) as well as

$65{ }^{137} \mathrm{Cs},{ }^{210} \mathrm{~Pb}$ and ${ }^{228} \mathrm{Ra}$ gamma spectrometry (Michels et al., 1998). Scarce hemipelagic layers

66 were excluded from the study in order to focus on turbiditic sediments representing the Ganga

$67 \&$ Brahmaputra detrital signal (Pierson-Wickmann et al., 2001; Weber et al., 1997). We

68 interpret our data by constructing a composite Log from the shelf and levees core following

69 the approach detailed in Galy et al. (2008).

River suspended river sediments were filtered through $0.22 \mu \mathrm{m}$ PES membrane filters within $24 \mathrm{~h}$ of sampling and dried in the lab. Major element concentration was determined by 
72 ICP-OES after $\mathrm{LiBO}_{2}$ fusion at SARM, Nancy - France (Carignan et al., 2001). Core samples

73 were repeatedly rinsed with water in order to remove salt contributions. Nevertheless, Na was

74 not considered in this study due to seawater contamination even after these rinsing steps.

75 Carbonate contents were measured manometrically from the $\mathrm{CO}_{2}$ released after reaction with

$76 \mathrm{H}_{3} \mathrm{PO}_{4}$ and the evolved $\mathrm{CO}_{2}$ was subsequently analyzed for $\mathrm{C}$ and $\mathrm{O}$ isotopic composition

77 (Galy et al., 1999). Sr and Nd isotopic compositions were measured on the acid leached,

78 silicate fraction of the river and core sediments by TIMS after classical separation and

79 purification by ion exchange resins. Sediment hydration $\left[\mathrm{H}_{2} \mathrm{O}^{+}\right]$and isotopic composition $\delta D-$

80 SMOW was measured by EA-IRMS after degassing the samples to remove adsorbed free-

81 water (Lupker et al., 2012b). The long-term reproducibility is better than $0.1 \mathrm{H}_{2} \mathrm{O}^{+} \mathrm{wt} \%$ and 2

$82 \%$ \%D-SMOW.

3. Sediment sorting effects on the chemical composition of detrital sediments:

$85 \quad 3.1$ Hydrodynamic control of sediment sorting

The chemical composition of river sediments has to be interpreted carefully. Sediment vertical depth profiles recovered from the water column of large rivers show a strong

89 heterogeneity in terms of concentration and chemical composition. These heterogeneities are

90 the result of the hydrodynamic sorting of sediments, based on grain-size, shape and density,

91 which induce mineralogical and thus chemical differentiation of sediments within the water

92 column (Bouchez et al., 2011a; Bouchez et al., 2011b; Garzanti et al., 2011; Lupker et al.,

93 2011; Singh and France-Lanord, 2002a). The mineralogy of sediments from the Himalayan

94 system is dominated by quartz, micas and feldspar, with occurrences of other phyllosilicates,

95 clay assemblages and hydroxides in the finer fraction (Garzanti et al., 2011; Garzanti et al.,

96 2010). These minerals are segregated during sediment transport: coarse-grained quartz is 
97 enriched in the bedload and at the bottom of the water column while phyllosilicates such as

98 micas and clays are comparatively enriched in the shallow surface waters of the river, leading

99 to a strong contrast in chemical composition between samples of a single reach. This is best

100 illustrated using the immobile element ratios $\mathrm{Fe} / \mathrm{Si}$ and $\mathrm{Al} / \mathrm{Si}$ (Figure 2). Fe, $\mathrm{Al}$ and $\mathrm{Si}$ are, to

101 a first order, immobile elements during Himalayan erosion and are thus not notably affected

102 by chemical weathering (Galy and France-Lanord, 2001). The sediments sampled across the

103 Indo-Gangetic plain form a unique mixing trend (to the exception of a few bedload samples

104 that are enriched in $\mathrm{Fe}$ due to heavy mineral placer effects) between quartz rich (low $\mathrm{Al} / \mathrm{Si}$

105 and $\mathrm{Fe} / \mathrm{Si}$ ) bottom sediments and clay rich (high $\mathrm{Al} / \mathrm{Si}$ and $\mathrm{Fe} / \mathrm{Si}$ ) surface sediments. $\mathrm{Al} / \mathrm{Si}$ and

$106 \mathrm{Fe} / \mathrm{Si}$ are directly correlated to the bulk sediment grain-size and are a proxy of mineral sorting

107 (Bouchez et al., 2011a; Lupker et al., 2011). A single sediment sample from a given river 108 reach can therefore not be considered, a priori, as representative of the whole sediment load, 109 its chemical composition being dependent on river hydrodynamics at the moment of 110 sampling.

\subsection{Weathering proxies in modern river sediments}

113

The degree of chemical weathering experienced by sediments in the Himalayan

115 system can be traced from detrital sediments by using the mobile to immobile elemental ratios 116 of river sediments such as $\mathrm{K} / \mathrm{Si}$ and $\mathrm{H}_{2} \mathrm{O}^{+} / \mathrm{Si}$. The structural hydroxyl content of sediments, $117 \mathrm{H}_{2} \mathrm{O}^{+}$, is a proxy of chemical weathering that traces mineral hydrolysis and secondary neo118 formations (Lupker et al., 2012b). Sediment sorting effects also apply to mobile elements 119 such as $\mathrm{K}$ and $\mathrm{H}_{2} \mathrm{O}^{+}$. The $\mathrm{K} / \mathrm{Si}$ and $\mathrm{H}_{2} \mathrm{O}^{+} / \mathrm{Si}$ ratios are dominantly controlled by the grain size 120 of the sediments, i.e. clay to quartz mixing (Lupker et al., 2012b) and are, to a first order, 121 linearly correlated to their A1/Si ratio as shown by Figure 3, where these ratios are plotted for 
122 sediments from the modern Himalayan system. By using a sediment depth profile sampling

123 approach on modern rivers, we characterize these sorting effects as this method allows 124 sampling a full set of sediments covering a wide range of grain sizes. The degree of chemical

125 weathering can then be assessed based on the trend formed by the chemical composition of

126 the sediments in diagrams such as Figure 3, this trend being representative of the entire

127 sediment load exported by the considered river.

128 In addition to silicate weathering proxies, we determined the calcite content and the

$129 \mathrm{Ca} / \mathrm{Si}$ ratio in Bay of Bengal sediments that reflects the carbonate weathering intensity in the

130 Himalayan system. Carbonates, including calcite, account for over $80 \%$ of the bulk Ca and

$131 \mathrm{Ca} / \mathrm{Si}$ therefore mainly reflects carbonate content. Both carbonates and $\mathrm{Ca}$ content are not 132 grain size dependent (Lupker et al., 2011) and are therefore not corrected for sediment 133 sorting.

\subsection{Accounting for sediment sorting effects in detrital records}

For detrital records such as the Bay of Bengal cores, changes in sediment transport and 138 deposition patterns induce changes in the grain size of deposited sediments that, in turn, affect 139 the chemical composition of the record. Hence, sediment sorting also has to be taken into 140 account in order to compare the degree of weathering of samples with variable grain-sizes 141 (variable $\mathrm{Al} / \mathrm{Si}$ ratios). However, unlike for modern rivers, it is not possible for a given age 142 interval of the record to recover a set of sediment samples spanning different grain sizes that 143 would fully describe the sediment weathering trend. By considering that each sample of the 144 Bay of Bengal record is the result of the mixing between a coarse-grained end-member, 145 similar to bedload material and a fine-grained, clay rich sediment, it is nevertheless possible 
146 to normalize mobile to immobile ratios $(\mathrm{X} / \mathrm{Si})$ to a common $\mathrm{Al} / \mathrm{Si}$ composition as illustrated 147 in Figure 4 and equation 1:

$$
\frac{X^{*}}{S i}=\frac{\overline{A l}}{S i} \cdot A+B
$$

149 where A and B are respectively the slope and intercept of the linear regression through the 150 sample and coarse grained end-member composition (Figure 4). Such normalized ratios allow 151 comparing the chemical composition of sediments that have contrasted grain sizes, while 152 properly accounting for sorting effects. Doing so, we assume that a unique coarse-grained 153 end-member composition can be assigned to the low $\mathrm{Al} / \mathrm{Si}$ mixing end-member and that the 154 weathering signature is mainly carried by the small grain size, clay fraction of the sediment 155 load. This is a reasonable approximation as: 1) contrary to the fine grained suspended load, no 156 systematic evolution of $\mathrm{K} / \mathrm{Si}$ and $\mathrm{H}_{2} \mathrm{O}^{+} / \mathrm{Si}$ ratios of modern bedloads in the Ganga basin is 157 detected from up to downstream (Lupker et al., 2012b), suggesting that the effect of chemical 158 weathering during transfer in the floodplain is negligible for the coarse fraction of the 159 transported sediments, and 2) the transfer time of bedload material is thought to be an order of 160 magnitude longer than that of fine-grained suspended load (Granet et al., 2010), which makes 161 it less sensitive than the suspended load to short-term upstream variations.

All corrected ratios presented here were normalized to a common $\mathrm{Al} / \mathrm{Si}$ value of 0.23 .

163 They are referred to as $\mathrm{X} / \mathrm{Si}^{*}$ and are listed in the supplementary information along with the 164 composition of the coarse grained end-member used in the calculations. The Al/Si value of 1650.23 was chosen as the average composition of the sediments exported by the modern Ganga, 166 which was determined by modeling the chemical composition of sediments as a function of 167 the river's hydrological conditions and integrated over a 25-year average hydrograph (Lupker 168 et al., 2011). This composition is also close to the composition of the Himalayan crust eroded 169 in the Ganga basin (Lupker et al., 2011). It should be noted that the choice of the Al/Si ratio used for normalizing $\mathrm{K} / \mathrm{Si}$ and $\mathrm{H}_{2} \mathrm{O}^{+} / \mathrm{Si}$ ratios only determines the absolute values of $\mathrm{K} / \mathrm{Si}^{*}$ 
171 and $\mathrm{H}_{2} \mathrm{O}^{+} / \mathrm{Si}^{*}$ but has no influence on the general trends observed for Bay of Bengal 172 sediments.

Before normalization, the raw $\mathrm{K} / \mathrm{Si}$ and $\mathrm{H}_{2} \mathrm{O}^{+} / \mathrm{Si}$ ratios of sediments from the Bay of

174 Bengal cores are correlated to $\mathrm{Al} / \mathrm{Si}$ (Figure 5), which supports that $\mathrm{K} / \mathrm{Si}$ and $\mathrm{H}_{2} \mathrm{O}^{+} / \mathrm{Si}$ are 175 dominantly controlled by grain size and sorting effects. However the normalized $\mathrm{K} / \mathrm{Si}^{*}$ and $176 \mathrm{H}_{2} \mathrm{O}^{+} / \mathrm{Si}^{*}$ ratios show no correlation with $\mathrm{Al} / \mathrm{Si}$, which suggests that our normalization 177 properly accounts for sediment sorting.

\subsection{Comparison with modern river sediments}

In order to compare the weathering degree of the Bay of Bengal sediment record to 182 modern river sediments we applied a similar normalization to the river sediments. The 183 average compositions of modern river sediments for elements prone to sorting effects $\left(\mathrm{K} / \mathrm{Si}^{*}\right.$, $\left.184 \mathrm{H}_{2} \mathrm{O}^{+} / \mathrm{Si}^{*}\right)$, reported in Figure 5, were determined by evaluating the regression through all 185 available data of each river reach and a coarse-grained end-member at $\mathrm{Al} / \mathrm{Si}=0.23$. The 186 Himalayan front end-member was reconstructed from the river sediments sampled at the 187 Himalayan front in the Ganga basin and the Brahmaputra basin separately assuming that ca. $18860 \%$ of the total sediment flux exported to the Bay of Bengal come from the Brahmaputra and 189 the remaining $40 \%$ come from the Ganga basin (RSP, 1996). For compositions that are not 190 affected by sorting effects (calcite, $\mathrm{Ca} / \mathrm{Si},{ }^{87} \mathrm{Sr} /{ }^{86} \mathrm{Sr}, \varepsilon \mathrm{Nd}, \delta^{18} \mathrm{O}$ and $\delta^{13} \mathrm{C}$ ), a simple average for 191 the Ganga, Brahmaputra and lower Meghna and a weighted mean for the Himalayan front 192 were considered (details can be found in supplementary information and Table S2).

194 4. Weathering in the Himalayan system:

$195 \quad 4.1$ Weathering in the modern system 
Chemical weathering is marked by a change in the mobile to immobile ratio at constant $\mathrm{Al} / \mathrm{Si}$ ratio. This mobile element depletion is highest for fine-grained (high $\mathrm{Al} / \mathrm{Si}$ )

199 sediments (Figure 3). Modern Himalayan rivers sediments, sampled at the front of the range 200 show high $\mathrm{K} / \mathrm{Si}$ ratios and low $\mathrm{H}_{2} \mathrm{O}^{+} / \mathrm{Si}$ ratios compared to the sediments sampled at the outlet 201 of the Ganga \& Brahmaputra basins and their confluence, the lower Meghna (Figure 3). The 202 loss of $\mathrm{K}$ and gain in hydration during floodplain transfer marks the weathering of the 203 sediments within the floodplain. Even if part of this weathering signal may stem from the 204 sediment contribution of the southern (Ganga) and eastern (Brahmaputra) tributaries, their 205 sediment fluxes remain small compared to that of Himalayan tributaries (Lupker et al., 2012b; 206 Singh and France-Lanord, 2002a). Calcite weathering in the modern floodplain is significant and leads to almost complete dissolution in Brahmaputra sediments in Bangladesh (Singh and 208 France-Lanord, 2002a; Singh et al., 2005) while modern Ganga sediments in Bangladesh 209 display a low calcite content of ca. $3 \mathrm{wt} \%$ (Lupker et al., 2012b).

It has been shown that in the modern Ganga basin, weathering within the floodplain 211 outweighs weathering within the Himalayan range (Lupker et al., 2012b; West et al., 2002).

212 Significant $\mathrm{K}$ depletion and $\mathrm{H}_{2} \mathrm{O}^{+}$gain is only recorded when sediments transit through the 213 floodplain (Lupker et al., 2012b), which is attributed to the longer residence time of sediments 214 in the floodplain than in the Himalayan range. Overall, these observations emphasize the 215 strong floodplain control on weathering in the Himalayan system. 4.2 Weathering record of the Bay of Bengal:

The normalized weathering indexes $\left(\mathrm{K} / \mathrm{Si}^{*}\right.$ and $\left.\mathrm{H}_{2} \mathrm{O}^{+} / \mathrm{Si}^{*}\right)$ are not biased by sorting 220 effects and can thus be applied to the Bay of Bengal record to reconstruct temporal variations 
221 in chemical weathering. Composite logs of $\mathrm{K} / \mathrm{Si}^{*}$ and $\mathrm{H}_{2} \mathrm{O}^{+} / \mathrm{Si}$ * (Figure 6) show a progressive 222 evolution towards lower $\mathrm{K} / \mathrm{Si}^{*}$ and higher $\mathrm{H}_{2} \mathrm{O}^{+} / \mathrm{Si}^{*}$ ratios from the LGM to present. Both 223 weathering proxies suggest that during the LGM, sediments exported to the Bay of Bengal 224 were less weathered than recent Bay of Bengal and modern lower-Meghna sediments. It 225 should also be noted that the chemical composition of sediments from the most recent part of 226 the Bay of Bengal record agrees well with that of the sediments currently exported by the 227 lower Meghna (Figure 6).

Calcite content and $\mathrm{Ca} / \mathrm{Si}$ ratios also decrease from LGM to present (Figure 6). Calcite

229 in sediments from the Bay of Bengal is of detrital origin as demonstrated by their isotopic 230 composition $\left(\delta^{18} \mathrm{O}_{\mathrm{PDB}}\right.$ ranging from -15 to $-6 \%$, see electronic appendix $)$, much lower than 231 marine biogenic calcite (Hoehndorf et al., 2003) and within the range of composition of 232 detrital Himalayan river calcite (Lupker et al., 2012b). The decrease in calcite concentration 233 and $\mathrm{Ca} / \mathrm{Si}$ ratios since the last glacial maximum supplement the $\mathrm{K} / \mathrm{Si}^{*}$ and $\mathrm{H}_{2} \mathrm{O}^{+} / \mathrm{Si}^{*}$ records, 234 further reinforcing the conclusion that sediment weathering increased during the studied 235 period.

$236 \quad$ Estuarine and early digenetic reactions such as weathering and reverse weathering 237 may affect the composition of deposited sediments (Jones et al., 2012; Michalopoulos and 238 Aller, 1995; Michalopoulos and Aller, 2004; Wallmann et al., 2008). The close agreement 239 between the chemical composition of modern lower Meghna sediments and the recent part of 240 the record, both from the shelf and the levee, suggests that estuarine processes do not alter 241 significantly the composition of river sediments delivered to the Bay of Bengal. The chemical 242 weathering of sediments after deposition cannot explain the trends observed in the Bay of 243 Bengal record either. Indeed, post-depositional weathering would lead to down-core increase 244 in the weathering intensity which is opposite to the observed trend. Reverse weathering leads 245 to an uptake of $\mathrm{K}$ and to an overall decrease in structural $\mathrm{OH}$ radicals of the sediments 
246 (Michalopoulos and Aller, 1995) but cannot explain the observed down-core increase in 247 detrital carbonate content. Furthermore, during reverse weathering reactions, the newly 248 formed minerals will form in equilibrium with seawater so that the $\mathrm{D} / \mathrm{H}$ isotopic composition 249 of their hydroxyls groups should become heavier as reverse weathering reactions proceed. 250 However no systematic down-core increase in $\delta \mathrm{D}_{\mathrm{H} 2 \mathrm{O}+}$ is observed (supplementary 251 information, Figure S1).

\section{Sediment provenance since the LGM:}

Potential sediment source effects on the chemical composition of Bay of Bengal 256 sediments since the LGM must be taken into account as changes in precipitation and erosion 257 patterns within and across the Himalayan range may have affected the sedimentary record. 258 The $\mathrm{Sr}$ and $\mathrm{Nd}$ isotopic signatures of river sediments in the Himalayan range are a first order 259 indicator of the erosion balance between the Lesser Himalaya (LH) and High Himalaya 260 (HHC) (and Transhimalayan formations - THB - for Brahmaputra) as these units have 261 contrasted isotopic compositions (France-Lanord et al., 1993; Singh and France-Lanord, 262 2002a). Sediments from the Ganga and Brahmaputra basins also show distinctive $\mathrm{Sr}$ and $\mathrm{Nd}$ 263 isotopic compositions so that changes in the balance of sediment supply from both basins 264 would be detected (Figure 7).

265 Previous studies have shown contrasting changes in the balance between sediments 266 from the LH and HHC in the Indus basin (Clift et al., 2008) and the western part of the Ganga 267 basin (Rahaman et al., 2009; Rahaman et al., 2010; Srivastava and Shukla, 2010) since 268 deglaciation. However, both $\mathrm{Sr}$ and $\mathrm{Nd}$ isotopic compositions of Bay of Bengal sediments 269 appear constant, implying that there is no evidence for major changes in the distribution of 270 erosion within the Himalayan range at this scale (Figure 7). The $\mathrm{Sr}$ and $\mathrm{Nd}$ record also 
271 suggests that the balance between the Brahmaputra and Ganga has remained roughly constant 272 over the last 20 kyrs. A significant change in the sediment balance between Ganga and 273 Brahmaputra would furthermore result in a correlated evolution of $\mathrm{K} / \mathrm{Si}^{*}$ and $\mathrm{H}_{2} \mathrm{O}^{+} / \mathrm{Si}^{*}$, 274 whereas these ratios are actually anti-correlated since the LGM (Figure 6), demonstrating that 275 the weathering signal overprints any potential change in sediment source.

276 An increase in sediments from the Siwalik or from southern tributaries through time is 277 also very unlikely. Siwalik rocks and sediments are characterized by high carbonate content 278 and low $\delta^{13} \mathrm{C}$ compositions (Lupker et al., 2012b; Sanyal et al., 2005). Thus, the concomitant 279 decrease of both carbonate content and $\delta^{13} \mathrm{C}$ values observed in the Bay of Bengal sediments 280 is not compatible with an increase of sediment supply from the Siwaliks. In addition, 281 sediments from the Chambal River in the Ganga basin and the Eastern tributaries of the 282 Brahmaputra basin (Lohit and Dibang) have distinctively higher Fe/Si ratios and unradiogenic 283 Sr and Nd signatures (Lupker et al., 2012b; Singh and France-Lanord, 2002a; Singh et al., 284 2008) that are not identified in our record (see supplementary information, Figure S1).

Altogether, the observed changes in Bay of Bengal sediment mobile elements composition since the LGM can thus be primarily attributed to changes in the chemical 288 weathering intensity in the Ganga \& Brahmaputra basin.

\section{Discussion:}

6.1 Climatic forcing of Himalayan chemical weathering

During the last 21 kyrs, climate has been the main external forcing of Himalayan 294 erosion that could have affected the Bay of Bengal weathering signal. Paleo-temperature reconstructions over the Himalayan system are scarce but indicate a ca. $2{ }^{\circ} \mathrm{C}$ colder LGM sea 
296 surface temperature (SST) in the Bay of Bengal (Kudrass et al., 2001). Hydrological changes 297 were significant with strongly reduced monsoon and therefore a lower continental runoff 298 during the last glacial (Cullen, 1981; Duplessy, 1982; Herzschuh, 2006; Kudrass et al., 2001), 299 which reduced the sediment supply to the Bay of Bengal (Goodbred, 2003; Weber et al., 300 1997). Precipitation and temperature directly control the weathering rate of minerals (White 301 and Blum, 1995), and the conditions during the LGM where therefore less favorable for 302 intense weathering in the floodplain. These changes in floodplain weathering are confirmed 303 by the evolution of clay assemblages in the southern part of the basin that suggests an 304 increase in weathering intensity from at least $10 \mathrm{kyr}$ to present (Heroy et al., 2003).

Additional, independent processes should not be excluded (Blum and Tornqvist, 306 2000). The lower base level and a reduced sediment supply during the LGM could have lead 307 to channel incision and a narrower active floodplain (Goodbred, 2003; Heroy et al., 2003), 308 which would reduce channel - floodplain interactions and limit the supply of weathered 309 floodplain sediments to the Bay of Bengal. A complete abandonment of the floodplain during 310 the LGM is nevertheless unlikely as floodplain derived organic material is persistent in the 311 Bay of Bengal cores throughout the deglaciation (Galy et al., 2008) but changes in the 312 sediment locus and volume being mobilized should not be excluded (Dosseto et al., 2010).

313 The weathering degree of sediments does, however, not show any clear change in 314 response to the decrease of monsoon intensity after the Holocene Climatic Optimum (HCO) 315 (Kudrass et al., 2001). The sediment fluxes during the HCO were up to double modern fluxes 316 as indicated by sediment volume reconstructions (Goodbred, 2003). These high sediment 317 fluxes may have obliterated the intense weathering conditions prevailing at that time. It can 318 also not be ruled out that modern sediments reflect the export of material weathered during 319 the HCO owing to a long-sediment transfer time so that the post-HCO decrease in 320 precipitation is not yet recorded in the Bay of Bengal. The impact of anthropogenic activity in 
321 the Indo-Gangetic floodplain should also be considered as intense land use changes, certainly 322 significant more than 3 centuries ago (Ramankutty and Foley, 1999), may overprint the

323 climatic forcing of the weathering degree in the recent part of the record if already significant

324 thousands of years ago (Bayon et al., 2012).

The sediment transfer time through the Himalayan system has to be considered as 327 well, as a long transfer time would induce a temporal offset between the suggested climatic 328 forcing of weathering in the Ganga \& Brahmaputra basin and its recording in the sediment 329 record of the Bay of Bengal. The sediment transfer time in large continental basins remains 330 difficult to constrain. U-series disequilibrium studies on Ganga sediments suggest that the 331 transfer time of coarse sediments may reach several 100 kyrs while fine grained suspended 332 material travel in less than 25 kyrs (Chabaux et al., 2009; Chabaux et al., 2006; Granet et al., 333 2010; Granet et al., 2007). However, simple mass balance considerations based on the volume 334 of the active floodplain and grain size along with modern sediment fluxes suggest shorter 335 transfer time scales of 1 kyrs for fine $(<100 \mu \mathrm{m})$ sediments along the Ganga floodplain 336 (Lupker et al., 2012a) and most probably even shorter transfer time along the narrower 337 Brahmaputra floodplain. In addition, short term variability of the chemical composition of 338 Ganga sediments observed in Bangladesh and attributed to the variable input of a $>1000 \mathrm{~km}$ 339 distant, upstream tributary suggests that for fine-grained suspended sediment the transfer time 340 can be of the order of the season (Lupker et al., 2012b). Finally, a relatively short transfer 341 time is also supported by the organic carbon Bay of Bengal record, which shows a change in 342 vegetation photosynthetic type over the Ganga \& Brahmaputra basin from the last glacial to 343 present (Galy et al., 2008). This vegetation change follows the model predictions and would 344 not be recorded if the sediment transfer time exceeded glacial - interglacial time scales. 
346 quantify, a network of evidences suggests that it is lower than glacial-interglacial time scales

347 for fine sediments such as those composing the Bay of Bengal record (high $\mathrm{Al} / \mathrm{Si}$ ratios).

348 Thus, the observed weathering trends most likely results from the direct or indirect climatic

349 forcing of weathering in the Ganga \& Brahmaputra basin.

\subsection{Towards a quantitative weathering budget}

Changes in the net weathering flux or dissolved flux $\left(\varphi_{\mathrm{X}}\right)$ can be estimated by

354 considering that, at steady state, the weathering flux exported as solutes to the oceans is the 355 product of the mobile element depletion of sediments $(\Delta \mathrm{X})$ and the sediment flux $\left(\mathrm{F}_{\text {sed }}\right)$ 356 (Lupker et al., 2012b):

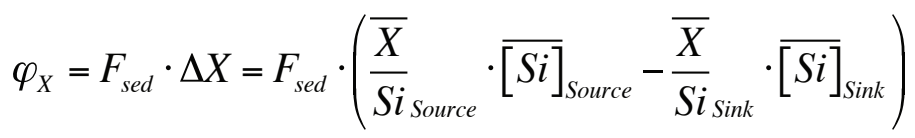

358 Where $\overline{X / S i}$ is the average mobile to immobile ratio of the source and sink sediments and

$359 \overline{[S i]}$ the average $\mathrm{Si}$ concentration of the sediments. A high-resolution reconstruction of

360 weathering fluxes is pointless, as the steady state hypothesis is likely not fully satisfied over

361 short time-scales because of late Holocene climatic variations and anthropogenic imprints

362 (possibly acting over timescales shorter than the sediment residence time in the floodplain). A

363 first order estimate can nevertheless be made by comparing the loss of $\mathrm{K}$, and gain in $\mathrm{H}_{2} \mathrm{O}^{+}$, 364 relative to Himalayan front sediments for the LGM (19- $22 \mathrm{kyr})$ and the modern $(0-2 \mathrm{kyr})$ 365 part of the record.

The average $\overline{\mathrm{K} / \mathrm{Si}}$ and $\overline{\mathrm{H}_{2} \mathrm{O}^{+} / \mathrm{Si}}$ ratios of the exported sediment flux can be 367 estimated based on the average $\mathrm{Al} / \mathrm{Si}$ ratio of the sediments, as $\mathrm{Al} / \mathrm{Si}$ is relatively insensitive 368 to chemical weathering. The average $\mathrm{Al} / \mathrm{Si}$ ratio of sediments was estimated to be 0.23 for the 369 Ganga in Bangladesh (Lupker et al., 2011). Hence, $\overline{\mathrm{K} / \mathrm{Si}}$ and $\overline{\mathrm{H}_{2} \mathrm{O}^{+} / \mathrm{Si}}$ are well 
370 approximated by $\overline{\mathrm{K} / \mathrm{Si}}{ }^{*}$ and $\overline{\mathrm{H}_{2} \mathrm{O}^{+} / \mathrm{Si}}{ }^{*}$, as for these ratios the composition of the sediment 371 is normalized to an $\mathrm{Al} / \mathrm{Si}$ ratio of 0.23 .

Because the effect of weathering in the Himalayan range is not detected on the $\mathrm{K} / \mathrm{Si}$

373 and $\mathrm{H}_{2} \mathrm{O}^{+} / \mathrm{Si}$ composition of modern river sediments sampled at the front of the Himalayan

374 range (Lupker et al., 2012b), we conclude that the composition of these sediments is a good

375 approximation of the average composition of the sediment source. This observation also

376 excludes the possibility of a significantly lower degree of sediment weathering within the

377 Himalayan range during the $\mathrm{LGM}$, as weathering for $\mathrm{K}$ and $\mathrm{H}_{2} \mathrm{O}^{+}$is already limited at present.

378 We therefore consider that the Himalayan front end-member (as constrained from the mixture

379 of $60 \%$ of sediments from the Himalayan front in the Brahmaputra basin and $40 \%$ in the

380 Ganga basin) is a good first order approximation of the sediment source composition, both in

381 the modern day system and during the LGM. The modern dissolved flux of Si is negligible

382 compared to the solid Si fluxes (Galy and France-Lanord, 2001) and this was most likely also

383 the case during the LGM as the chemical weathering intensity was even lower than at present.

384 Furthermore the Si concentration of the exported sediments is only slightly affected by

385 sequestration of Si-rich bedload sediments in the modern floodplain (Lupker et al., 2012b)

386 and we make the assumption that this has been true during the last 21 kyrs. Hence, we

387 consider $\overline{[S i}$ constant during the time span of our record.

389 relative to the modern fluxes can therefore be written as:

$$
\begin{aligned}
& R \varphi_{X}=\frac{\left.\varphi_{X}\right|_{\text {Modern }}-\left.\varphi_{X}\right|_{L G M}}{\left.\varphi_{X}\right|_{\text {Modern }}} \\
& =\frac{F_{\text {Sed }}^{\text {Modern }} \cdot\left(X /\left.S i\right|_{\text {HimalFront }} ^{\text {Modern }}-X /\left.S i\right|_{\text {BoB }} ^{\text {Modern }}\right)-F_{\text {Sed }}^{L G M} \cdot\left(X /\left.S i\right|_{\text {HimalFront }} ^{L G M}-X /\left.S i *\right|_{\text {BoB }} ^{L G M}\right)}{F_{\text {Sed }}^{\text {Modern }} \cdot\left(X /\left.S i\right|_{\text {HimalFront }} ^{\text {Modern }}-X /\left.S i\right|_{\text {BoB }} ^{\text {Modern }}\right)}
\end{aligned}
$$


391 In order to estimate $\mathrm{R} \varphi_{\mathrm{x}}$ from eq. 3 , the sediment flux $\left(\mathrm{F}_{\text {sed }}\right)$ has to be estimated at present and 392 during the LGM. Based on extensive gauging data the combined modern flux of the Ganga \& 393 Brahmaputra in Bangladesh is estimated to be ca. $1.10^{9}$ t. $^{-1} r^{-1}$ (RSP, 1996). The past sediment 394 flux exported by the Ganga \& Brahmaputra is largely unknown. However, qualitatively, the 395 sediment flux was most probably lower during the LGM than at present. A weakened 396 monsoon during the LGM (Kudrass et al., 2001; Sharma et al., 2004) may have limited 397 physical erosion in the Himalayan range and lowered the transport capacity of the rivers, 398 leading to a lower sediment flux to the Bay of Bengal (Weber et al., 1997; Goodbred, 2003). 399 A very conservative estimate of the minimum value of $\mathrm{R} \varphi_{\mathrm{X}}$ can therefore be made assuming a 400 constant sediment flux over the period. By doing so we also isolate the effect of the change in 401 the chemical composition of sediments only. $\mathrm{R} \varphi$ was computed using eq. 3 for $\mathrm{K}$ and $\mathrm{H}_{2} \mathrm{O}^{+}$and is summarized in Table 1 . 403 Uncertainties on the $\mathrm{K} / \mathrm{Si}^{*}$ and $\mathrm{H}_{2} \mathrm{O}^{+} / \mathrm{Si}^{*}$ ratios of individual samples are ca $3 \%$ 404 (supplementary information S3). This is of the same order as the variability of $\mathrm{K} / \mathrm{Si}^{*}$ and $405 \mathrm{H}_{2} \mathrm{O}^{+} / \mathrm{Si}^{*}$ ratios over the $0-2$ and $19-22 \mathrm{kyr}$ intervals or of the uncertainties on the regression 406 through the data for the Himalayan front sediments. These uncertainties were propagated 407 through the calculations of $\mathrm{R} \varphi \mathrm{x}$ and reported in Table 1 . The sensitivity of the weathering 408 budget to the average $\mathrm{Al} / \mathrm{Si}$ ratio of sediments is lower than the uncertainty propagated from 409 the variability of $\mathrm{K} / \mathrm{Si}^{*}$ and $\mathrm{H}_{2} \mathrm{O}^{+} / \mathrm{Si}^{*}$ ratios (see supplementary information $\mathrm{S} 3$ ). This first 410 order estimation shows that the weathering flux during the LGM was at least $67( \pm 28)$ and 89 411 ( \pm 36$) \%$ lower (for $\mathrm{K}$ and $\mathrm{H}_{2} \mathrm{O}^{+}$, respectively) than for the modern period $(0-2$ kyrs) for a 412 constant sediment flux. The main uncertainty on these estimates comes from the uncertainty 413 on the sediment Ganga and Brahmaputra sediment flux during the LGM. A sediment flux 414 during the LGM of half the present day sediment flux would induce a 83 and $95 \%$ lower 415 weathering flux during the LGM compared to present for $\mathrm{K}$ and $\mathrm{H}_{2} \mathrm{O}^{+}$, respectively. 
The loss of $\mathrm{K}$ in the Himalayan system is mainly attributed to the weathering of biotite

418 while the gain in hydration also depends on clay secondary mineral formation (Lupker et al.,

419 2012). Because the reaction mechanisms in both cases are different, their sensitivity to 420 changes in precipitation and temperature is also most probably different. Despite our 421 estimates for both proxies being similar within uncertainty, it would not be surprising that the 422 relative changes in weathering fluxes recorded by $\mathrm{K}$ and $\mathrm{H}_{2} \mathrm{O}^{+}$could be different. It is not 423 possible to estimate the relative change in calcite weathering using a similar approach, 424 because for calcite the Himalayan source composition cannot be reliably estimated. Indeed, 425 significant carbonate dissolution has been documented within the Himalayan range (Galy and 426 France-Lanord, 1999), hence, Himalayan front river sediments cannot accurately represent the 427 eroded source. In addition, no direct estimation of the average calcite content of Himalayan 428 rocks is available.

429 Our quantification of the change in the net weathering flux from LGM to present 430 should only be considered as a rough estimate. In particular, it should be kept in mind that 431 these estimates somewhat depend upon the assumption of a transition between two steady 432 state weathering stages. Nevertheless, our estimates suggest that changes in weathering fluxes 433 exported by the Himalayan system have been significant over short time scales of ca. 20 kyrs. 434 The magnitude of the variations in weathering fluxes reconstructed here exceeds previous 435 estimates (Foster and Vance, 2006). This may be attributed in part to the very high weathering 436 rates of glacial outwash during the very early stage of an interglacial, as proposed earlier 437 (Foster and Vance, 2006; Vance et al., 2009) combined to the short time span of our record. 438 However, for the Himalayan system the weathering intensity in the modern floodplain 439 (Lupker et al., 2012b; West et al., 2002) supports the dominant role of the floodplain in 440 modulating glacial to interglacial weathering fluxes. This study further emphasizes that 
441 present day weathering rates are likely higher than long-term averages, which supports the

442 idea that the imbalance of oceanic geochemical cycles may at least partially derive from the

443 over-estimation of Quaternary riverine fluxes to the oceans (Vance et al., 2009).

\section{Conclusions:}

The geochemistry of detrital sediment records holds valuable information on the

448 weathering regime these sediments have undergone during their transit from sediment

449 producing areas to their deposition in sedimentary basins. The chemical composition of these

450 sediments is primarily controlled by sediment sorting effects that occur during transport and

451 deposition. Nevertheless weathering signals can be extracted from the sediment chemical 452 composition if sorting is properly taken into account by comparing sediment records to 453 modern river systems.

454 The detrital record presented here shows that the degree of chemical weathering 455 experienced by sediments exported by the Himalayan system, drained by the Ganga and 456 Brahmaputra Rivers, has changed significantly since the LGM. An overall decrease in 457 potassium and detrital calcite content along with an increase in sediment hydration all point 458 towards a steady increase in the weathering degree of sediments over the last 21 kyrs, while 459 the sediment provenance has remained unchanged. These changes in the weathering regime 460 are attributed to the direct climatic forcing of chemical weathering in the floodplain, as 461 increasing precipitation and temperatures after the deglaciation favored mineral weathering 462 kinetics. Additional hydrological changes in response to increasing runoff and rising base 463 level might also have impacted weathering through enhanced channel-floodplain interactions. 
466 shows that weathering fluxes from the Himalayan system could have been reduced by $90 \%$

467 during the LGM. This supports previous evidence that current dissolved fluxes are likely

468 higher than average Quaternary estimates. These drastic changes in solute supply to the

469 oceans on glacial-interglacial time scales have to be accounted for to reconstruct global $470 \quad$ oceanic biogeochemical cycles.

471

$472 \quad$ Acknowledgments:

473 This work was supported by French INSU program "Relief de la Terre" and ANR

474 Calimero. V.G. was supported by the U.S. National Science Fundation (Grant OCE-0851015,

475 OCE-0928582). We thank C. Guilmette for assistance in the lab. H. Schopka and two 476 anonymous reviewers are also thanked for their constructive comments that helped to improve

477 the manuscript. T.M. Harrison is acknowledged for the very efficient handling of the 478 manuscript. 
$\begin{array}{ll}480 & \text { Bayon, G., Dennielou, B., Etoubleau, J., Ponzevera, E., Toucanne, S., Bermell, S., } 2012 . \\ 481 & \text { Intensifying Weathering and Land Use in Iron Age Central Africa. Science 335, 1219- }\end{array}$ 1222. 10.1126/science.1215400

Blum, M.D., Tornqvist, T.E., 2000. Fluvial responses to climate and sea-level change: a review and look forward. Sedimentology 47, 2-48.

Bouchez, J., Gaillardet, J., France-Lanord, C., Maurice, L., Dutra-Maia, P., 2011a. Grain size control of river suspended sediment geochemistry: Clues from Amazon River depth profiles. Geochem. Geophys. Geosyst. 12, Q03008. 10.1029/2010gc003380

Bouchez, J., Lupker, M., Gaillardet, J., France-Lanord, C., Maurice, L., 2011b. How important is it to integrate riverine suspended sediment chemical composition with depth? Clues from Amazon River depth-profiles. Geochimica Et Cosmochimica Acta 75, 6955-6970. 10.1016/j.gca.2011.08.038

Carignan, J., Hild, P., Mevelle, G., Morel, J., Yeghicheyan, D., 2001. Routine analyses of trace elements in geological samples using flow injection and low pressure on-line liquid chromatography coupled to ICP-MS: A study of geochemical reference materials BR, DR-N, UB-N, AN-G and GH. Geostandards Newsletter-the Journal of Geostandards and Geoanalysis 25, 187-198.

Chabaux, F., Granet, M., Blaes, E., Dosseto, A., France-Lanord, C., Valier, V., 2009. Determination of source and transfer-time of river sediments in alluvial plain from $U$ series nuclides: Evidence from the Ganges River System. Geochimica Et Cosmochimica Acta 73, A203-A203.

Chabaux, F., Granet, M., France-Lanord, C., Stille, P., 2006. U-series in Himalayan rivers: Timescale of sedimentary transfer. Geochimica Et Cosmochimica Acta 70, A92A92. 10.1016/j.gca.2006.06.097|ISSN 0016-7037

Clift, P.D., Giosan, L., Biusztajn, J., Campbell, I.H., Allen, C., Pringle, M., Tabrez, A.R., Danish, M., Rabbani, M.M., Alizai, A., Carter, A., Lueckge, A., 2008. Holocene erosion of the Lesser Himalaya triggered by intensified summer monsoon. Geology 36, 79-82. 10.1130/g24315a.1|issn 0091-7613

Cullen, J.L., 1981. Microfossil evidence for changing salinity patterns in the Bay of Bengal over the last 20000 years. Palaeogeography Palaeoclimatology Palaeoecology 35, 315-356.

Dosseto, A., Hesse, P.P., Maher, K., Fryirs, K., Turner, S., 2010. Climatic and vegetation control on sediment dynamics during the last glacial cycle. Geology 38, 395-398. 10.1130/g30708.1

Duplessy, J.C., 1982. Glacial to interglacial contrasts in the northern Indian Ocean, . Nature 295, 494-498.

Foster, G.L., Vance, D., 2006. Negligible glacial-interglacial variation in continental chemical weathering rates. Nature 444, 918-921. 10.1038/nature 05365

France-Lanord, C., Derry, L., 1997. Organic carbon burial forcing of the carbon cycle from Himalayan erosion. Nature 390, 65-66.

France-Lanord, C., Derry, L., Michard, A., 1993. Evolution of the Himalaya since Miocene time: isotopic and sedimentologic evidence from the Bengal Fan, in: Treloar, P.J., Searle, M. (Eds.), Himalayan Tectonics. Geol. Soc. Lond., London, pp. 603-621.

Galy, A., France-Lanord, C., 2001. Higher erosion rates in the Himalaya: Geochemical constraints on riverine fluxes. Geology 29, 23-26.

Galy, A., France-Lanord, C., Derry, L.A., 1999. The strontium isotopic budget of Himalayan Rivers in Nepal and Bangladesh. Geochimica Et Cosmochimica Acta 63, 1905-1925. 
Galy, V., François, L., France-Lanord, C., Faure, P., Kudrass, H., Palhol, F., Singh, S., 2008. C4 plants decline in the Himalayan basin since the Last Glacial Maximum. Garzanti, E., Ando, S., France-Lanord, C., Censi, P., Vignola, P., Galy, V., Lupker, M., 2011. Mineralogical and chemical variability of fluvial sediments 2 . Suspended-load silt (Ganga-Brahmaputra, Bangladesh). Earth and Planetary Science Letters 302, 107-120. 10.1016/j.epsl.2010.11.043

Garzanti, E., Ando, S., France-Lanord, C., Vezzoli, G., Censi, P., Galy, V., Najman, Y., 2010. Mineralogical and chemical variability of fluvial sediments 1 . Bedload sand (Ganga-Brahmaputra, Bangladesh). Earth and Planetary Science Letters 299, 368-381. 10.1016/j.epsl.2010.09.017

Goodbred, S.L., 2003. Response of the Ganges dispersal system to climate change: a source-to-sink view since the last interstade. Sedimentary Geology 162, 83-104.

Granet, M., Chabaux, F., Stille, P., Dosseto, A., France-Lanord, C., Blaes, E., 2010. Useries disequilibria in suspended river sediments and implication for sediment transfer time in alluvial plains: The case of the Himalayan rivers. Geochimica Et Cosmochimica Acta 74, 2851-2865. 10.1016/i.gca.2010.02.016

Granet, M., Chabaux, F., Stille, P., France-Lanord, C., Pelt, E., 2007. Time-scales of sedimentary transfer and weathering processes from U-series nuclides: Clues from the Himalayan rivers. Earth and Planetary Science Letters 261, 389-406. 10.1016/j.epsl.2007.07.012|ISSN 0012-821X

Heroy, D., Kuehl, S., Goodbred, S., 2003. Mineralogy of the Ganges and Brahmaputra rivers: Implications for river switching and Late Quaternary climate change. Sedimentary Geology 155, 343-359.

Herzschuh, U., 2006. Palaeo-moisture evolution in monsoonal Central Asia during the last 50,000 years. Quaternary Science Reviews 25, 163-178.

Hoehndorf, A., Kudrass, H.R., France-Lanord, C., 2003. Transfer of the Sr isotopic signature of the Himalayas to the Bay of Bengal. Deep-Sea Research Part Ii-Topical Studies in Oceanography 50, 951-960. 10.1016/s0967-0645(02)00614-8|issn 0967-0645

Ittekkot, V., Kudrass, H.R., Quadfasel, D., Unger, D., 2003. The Bay of Bengal--An Introduction. Deep Sea Research Part II: Topical Studies in Oceanography 50, 853-854. Jones, M.T., Pearce, C.R., Oelkers, E.H., 2012. An experimental study of the interaction of basaltic riverine particulate material and seawater. Geochimica Et Cosmochimica Acta 77, 108-120. 10.1016/j.gca.2011.10.044

Kudrass, H., Hofmann, A., Doose, H., Emeis, K., Erlenkeuser, H., 2001. Modulation and amplification of climatic changes in the Northern Hemisphere by the Indian summer monsoon during the past 80 k.y. Geology 29, 63-66.

Limmer, D.R., B^ning, P., Giosan, L., Ponton, C., K^hler, C.M., Cooper, M.J., Tabrez, A.R., Clift, P.D., 2012. Geochemical record of Holocene to Recent sedimentation on the Western Indus continental shelf, Arabian Sea. Geochem. Geophys. Geosyst. 13, Q01008. 10.1029/2011gc003845

Lupker, M., Blard, P.-H., Lavé, J., France-Lanord, C., Leanni, L., Puchol, N., Charreau, J., Bourlès, D., 2012a. 10Be-derived Himalayan denudation rates and sediment budgets in the Ganga basin. Earth and Planetary Science Letters 333-334, 146-156. 10.1016/j.epsl.2012.04.020

Lupker, M., France-Lanord, C., Galy, V., Lave, J., Gaillardet, J., Gajurel, A.P., Guilmette, C., Rahman, M., Singh, S.K., Sinha, R., 2012b. Predominant floodplain over mountain weathering of Himalayan sediments (Ganga basin). Geochimica Et Cosmochimica Acta 84, 410-432. 10.1016/j.gca.2012.02.001 
Lupker, M., France-Lanord, C., Lavè, J., Bouchez, J., Galy, V., MÈtivier, F., Gaillardet, J., Lartiges, B., Mugnier, J.-L., 2011. A Rouse-based method to integrate the chemical composition of river sediments: Application to the Ganga basin. J. Geophys. Res. 116, F04012. 10.1029/2010jf001947

Michalopoulos, P., Aller, R.C., 1995. Rapid Clay Mineral Formation in Amazon Delta Sediments: Reverse Weathering and Oceanic Elemental Cycles. Science 270, 614.

Michalopoulos, P., Aller, R.C., 2004. Early diagenesis of biogenic silica in the Amazon delta: alteration, authigenic clay formation, and storage. Geochimica Et Cosmochimica Acta 68, 1061-1085. 10.1016/j.gca.2003.07.018

Michels, K.H., Kudrass, H.R., H,bscher, C., Suckow, A., Wiedicke, M., 1998. The submarine delta of the Ganges-Brahmaputra: cyclone-dominated sedimentation patterns. Marine Geology 149, 133-154.

Pierson-Wickmann, A.-C., Reisberg, L., France-Lanord, C., Kudrass, H., 2001. Os-SrNd results from sediments in the Bay of Bengal: Implications for sediment transport and the marine Os record. Paleoceanography 16, 435-444.

Rahaman, W., Singh, S.K., Sinha, R., Tandon, S.K., 2009. Climate control on erosion distribution over the Himalaya during the past $\sim 100$ ka. Geology 37, 559-562. 10.1130/g25425a.1

Rahaman, W., Singh, S.K., Sinha, R., Tandon, S.K., 2010. Climate control on erosion distribution over the Himalaya during the past similar to 100 ka: REPLY. Geology 38, E217-E217. 10.1130/g31119y.1

Ramankutty, N., Foley, J.A., 1999. Estimating historical changes in global land cover: Croplands from 1700 to 1992. Global Biogeochem. Cycles 13, 997-1027. 10.1029/1999gb900046

Raymo, M., Ruddiman, W., Froelich, P., 1988. Influence of late Cenozoic mountain building on ocean geochemical cycles. Geology 16, 649.

Reimer, P.J., Baillie, M.G.L., Bard, E., Bayliss, A., Beck, J.W., Blackwell, P.G., Ramsey, C.B., Buck, C.E., Burr, G.S., Edwards, R.L., Friedrich, M., Grootes, P.M., Guilderson, T.P., Hajdas, I., Heaton, T.J., Hogg, A.G., Hughen, K.A., Kaiser, K.F., Kromer, B., McCormac, F.G., Manning, S.W., Reimer, R.W., Richards, D.A., Southon, J.R., Talamo, S., Turney, C.S.M., van der Plicht, J., Weyhenmeye, C.E., 2009. Intcal09 and Marine09 Radiocarbon Age Calibration Curves, 0-50,000 Years Cal Bp. Radiocarbon 51, 1111150.

RSP, 1996. River Survey Project, Flood Action Plan (FAP) final report. Delft Hydraulics and DHI.

Sanyal, P., Bhattacharya, S.K., Prasad, M., 2005. Chemical diagenesis of Siwalik sandstone: Isotopic and mineralogical proxies from Surai Khola section, Nepal. Sedimentary Geology 180, 57-74.

Sharma, S., Joachimski, M., Sharma, M., Tobschall, H.J., Singh, I.B., Sharma, C., Chauhan, M.S., Morgenroth, G., 2004. Lateglacial and Holocene environmental changes in Ganga plain, Northern India. Quaternary Science Reviews 23, 145-159.

Singh, S., France-Lanord, C., 2002a. Tracing the distribution of erosion in the Brahmaputra watershed from isotopic compositions of stream sediments. Earth and Planetary Science Letters 252, 645-662.

Singh, S.K., France-Lanord, C., 2002b. Erosion distribution in the Eastern Himalaya traced by Sr-Nd isotopic compositions of river sediments. Geochimica Et Cosmochimica Acta 66, A720-A720.

Singh, S.K., Rai, S.K., Krishnaswami, S., 2008. Sr and Nd isotopes in river sediments from the Ganga Basin: Sediment provenance and spatial variability in physical erosion. J. Geophys. Res. 113, F03006. 10.1029/2007jf000909 
Singh, S.K., Sarin, M.M., France-Lanord, C., 2005. Chemical erosion in the eastern Himalaya: Major ion composition of the Brahmaputra and delta C-13 of dissolved inorganic carbon. Geochimica Et 10.1016/j.gca.2005.02.033|ISSN 0016-7037 Srivastava, P., Shukla, U.K., 2010. Climate control on erosion distribution over the Himalaya during past similar to 100 ka: COMMENT. Geology 38, E216-E216. $\underline{10.1130 / g 30838 c .1}$

Vance, D., Teagle, D.A.H., Foster, G.L., 2009. Variable Quaternary chemical weathering fluxes and imbalances in marine geochemical budgets. Nature 458, 493-496. 10.1038/nature07828

640 Wallmann, K., Aloisi, G., Haeckel, M., Tishchenko, P., Pavlova, G., Greinert, J., Walker, J., Hays, P., Kasting, J., 1981. A negative feedback mechanism for the longterm stabilization of the Earth's surface temperature. Journal of Geophysical Research 86, 9776-9782. Kutterolf, S., Eisenhauer, A., 2008. Silicate weathering in anoxic marine sediments. Geochimica Et Cosmochimica Acta 72, 2895-2918.

Weber, M.E., Wiedicke, M.H., Kudrass, H.R., Hübscher, C., Erlenkeuser, H., 1997. Active growth of the bengal Fan during sea-level rise and highstand. Geology 25, 315318. on Himalayan weathering fluxes. Geology 30, 355-358. 10.1130/00917613(2002)030<0355:scpohw $>2.0 . c 0 ; 2$ 


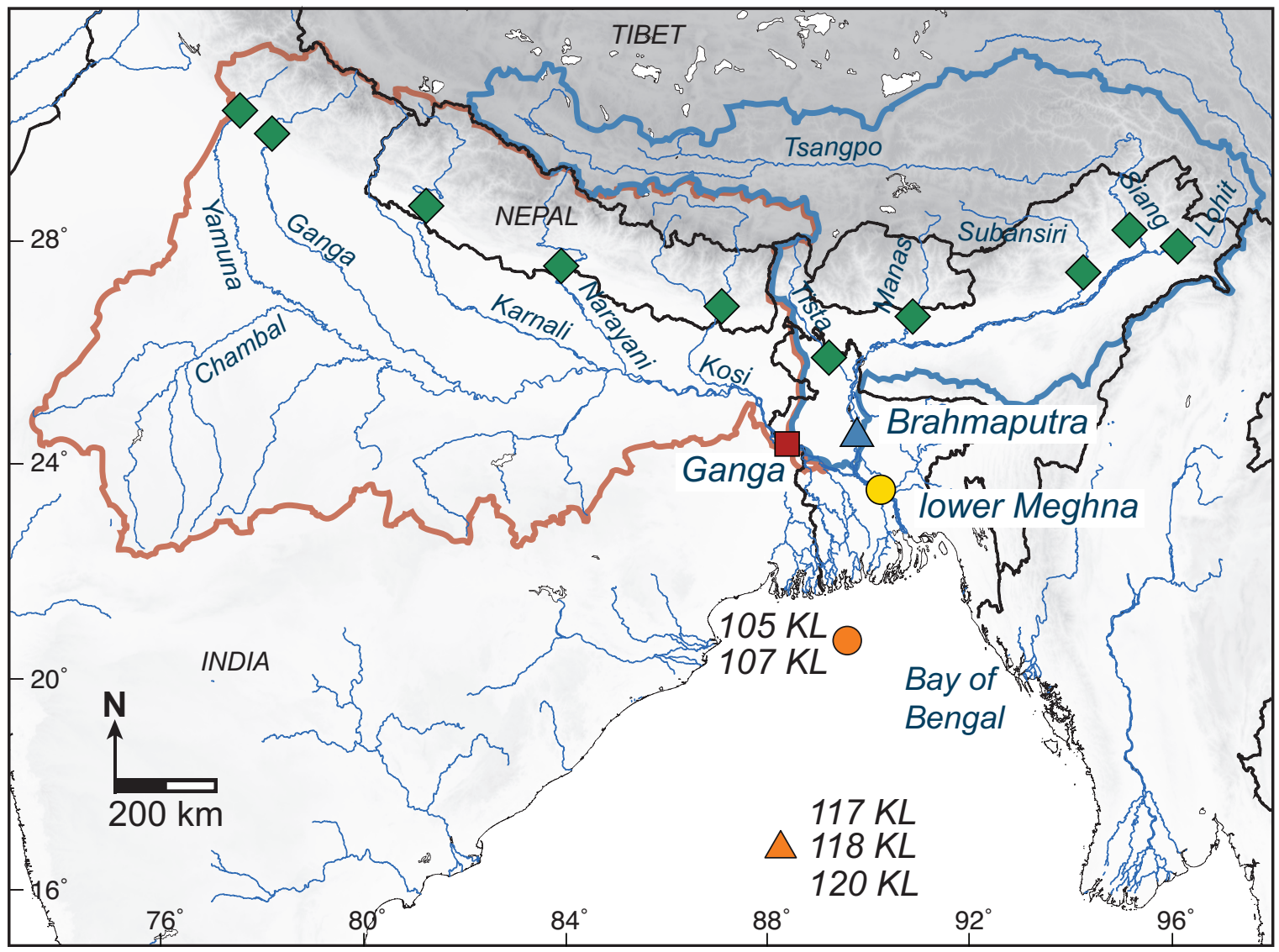

659 Figure 1: Geographical setting of the Himalayan system. Modern river sediments were sampled in the Ganga \& Brahmaputra basin at the Himalayan front (green diamonds), at the outlet of the Ganga basin (red square) and the Brahmaputra basin (blue triangle) and finally after their confluence in the lower Meghna (yellow circle). These sediments were compared to the sediment record of the Bay of Bengal that represents a composite record from proximal shelf sediments (105KL and 107KL) and from the middle fan channel levees (117KL, 118KL and 120KL). 


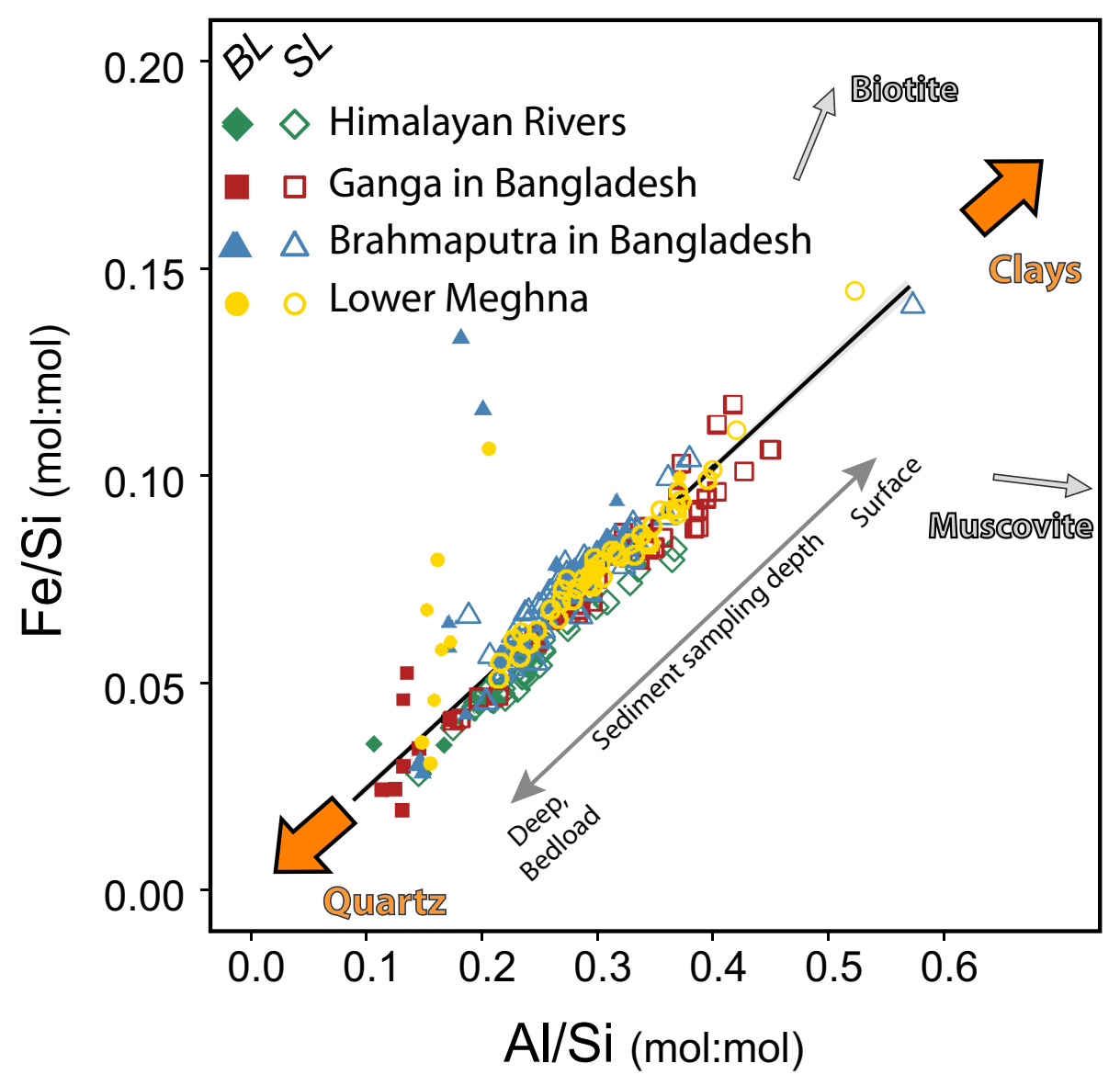

668 Figure 2: Hydraulic sorting effect on the Si-Al-Fe chemical composition of sediments.

669 Suspended sediments are the result of the mixing between a low $\mathrm{Al} / \mathrm{Si}$ and $\mathrm{Fe} / \mathrm{Si}$

670 quartz-rich coarse-grained end-member and a high $\mathrm{Al} / \mathrm{Si}$ and $\mathrm{Fe} / \mathrm{Si}$ surface end671 member relatively enriched in phylosilicates.

672 

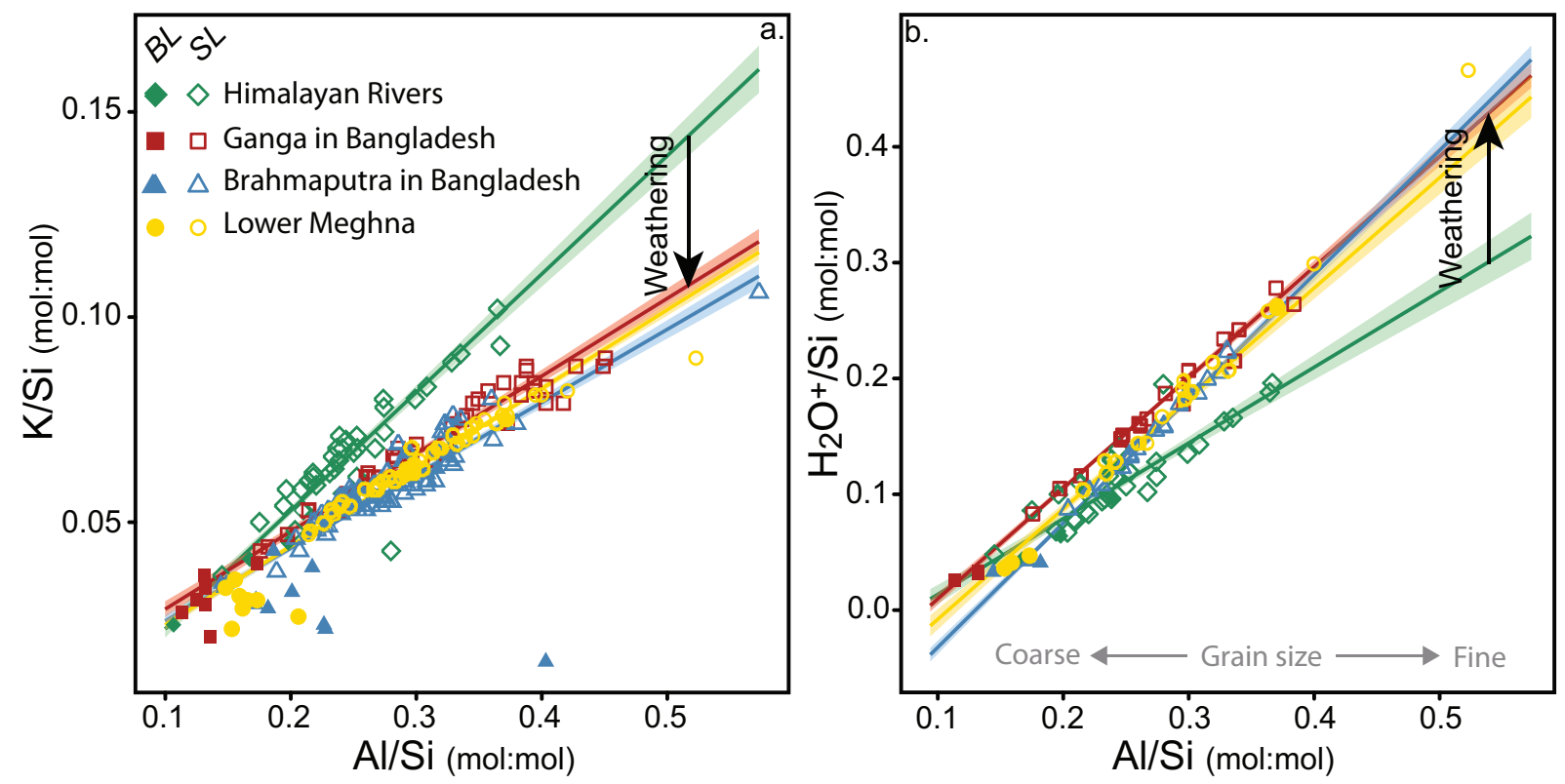

674 Figure 3: Evolution of $\mathrm{K} / \mathrm{Si}$ (a) and $\mathrm{H}_{2} \mathrm{O}^{+} / \mathrm{Si}(\mathrm{b})$ in the modern Himalayan system for river suspended load (SL) and bedload or bar sediments (BL). The transfer of sediments from the Himalayan front Rivers (green) to the outlet of the Ganga (red) and Brahmaputra (blue), as well as their confluence the lower-Meghna (yellow) results in a loss of $\mathrm{K}$ and an increase in $\mathrm{H}_{2} \mathrm{O}^{+}$as weathering proceeds. Envelopes represent 0.95 confidence level on the linear regression. 


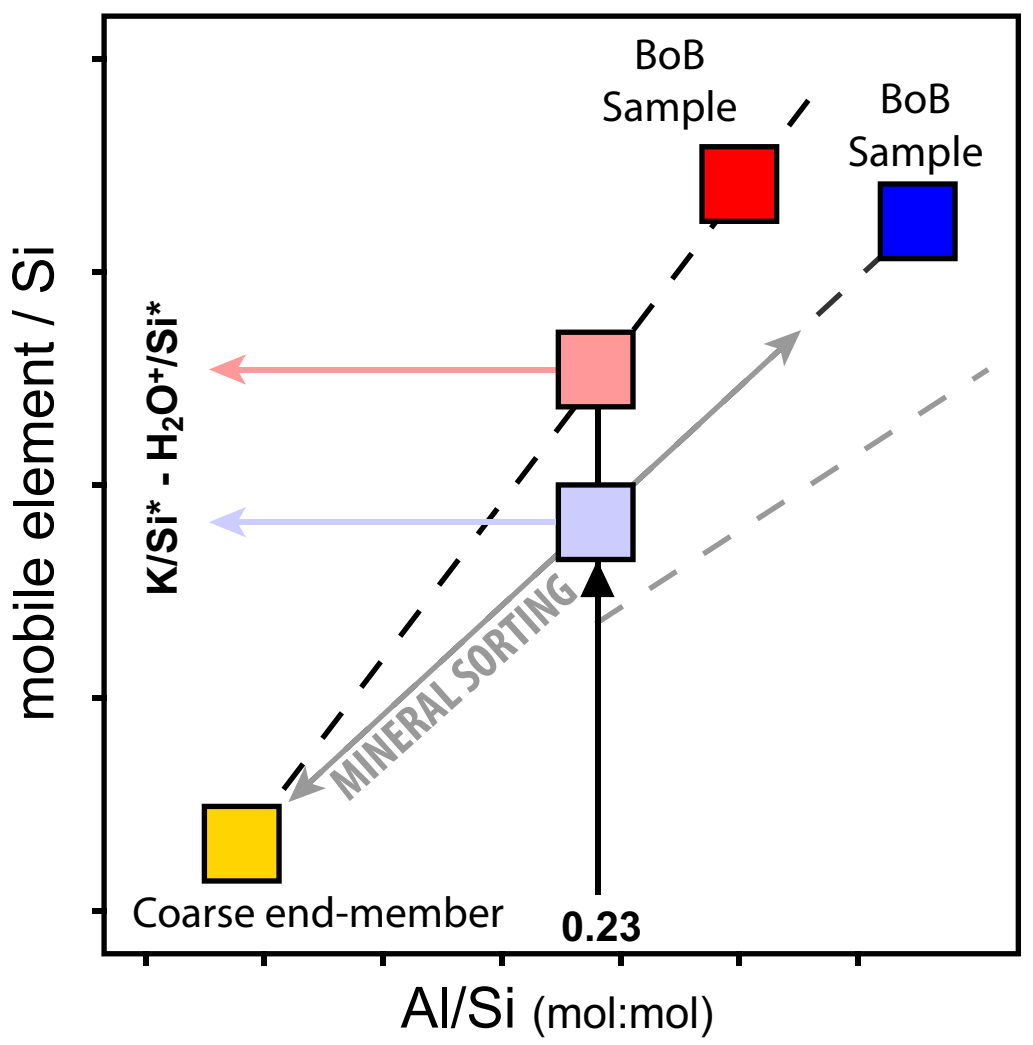

$681 \quad$ Figure 4: Normalization of the chemical composition of sediments in of the Bay of Bengal record for hydraulic sorting effects. The $\mathrm{K} / \mathrm{Si}$ and $\mathrm{H}_{2} \mathrm{O}^{+} / \mathrm{Si}$ ratios of the sample are normalized to a common $\mathrm{Al} / \mathrm{Si}$ ratio of 0.23 assuming that the sediment sorting line passes through a unique coarse-grained end-member with a composition close to river bedloads (given in the supplementary information, Table S1). 

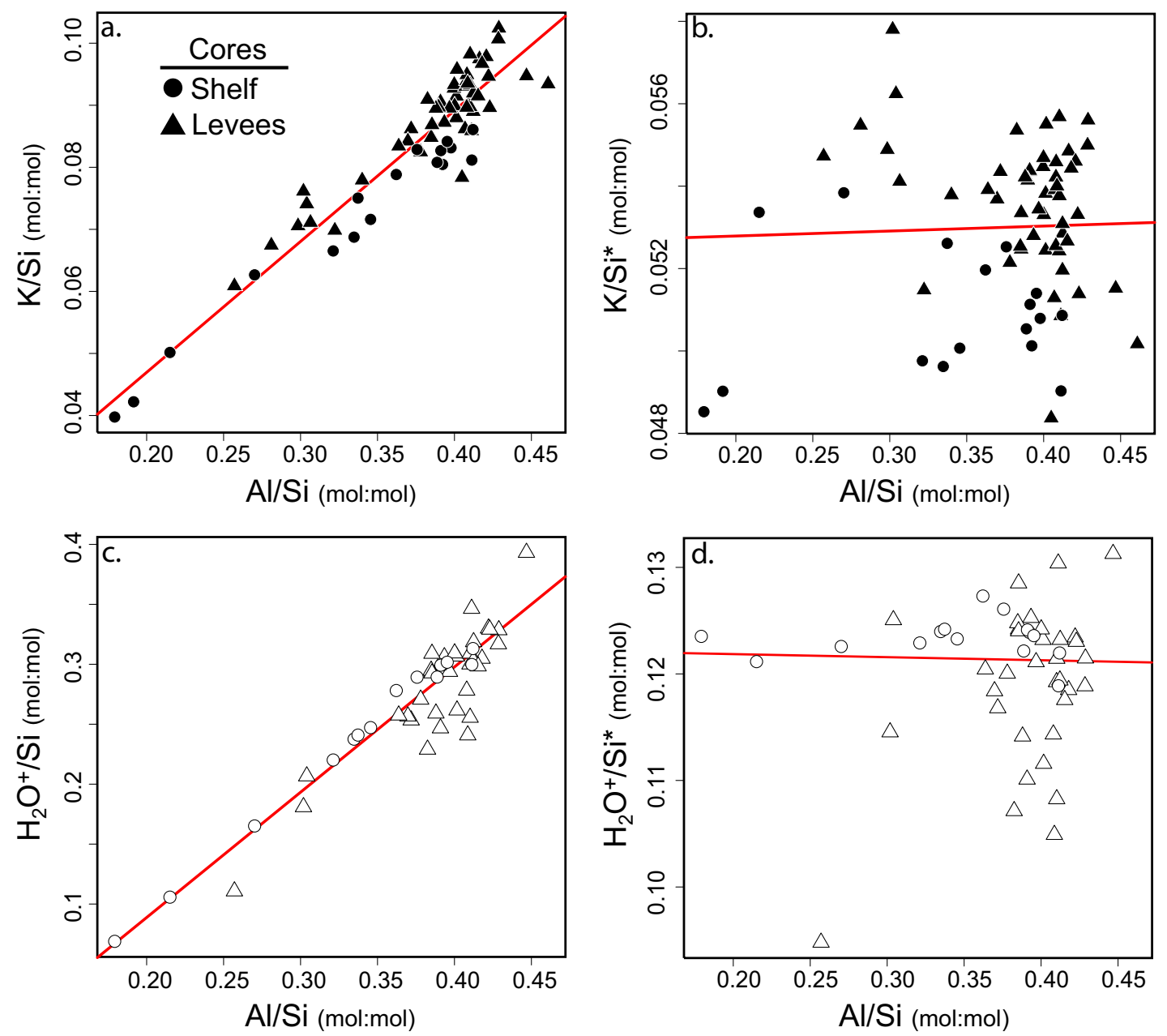

687 Figure 5: $\mathrm{K} / \mathrm{Si}$ and $\mathrm{H}_{2} \mathrm{O}^{+} / \mathrm{Si}$ in Bay of Bengal core sediments are strongly correlated to $\mathrm{Al} / \mathrm{Si}$, which is a proxy for grain size (Bouchez et al., 2011a; Lupker et al., 2011). Correction for hydraulic mineral sorting yields unbiased weathering indicators $\left(\mathrm{K} / \mathrm{Si}^{*}\right.$ and

690 $\left.\mathrm{H}_{2} \mathrm{O}^{+} / \mathrm{Si}^{*}\right)$.

691 


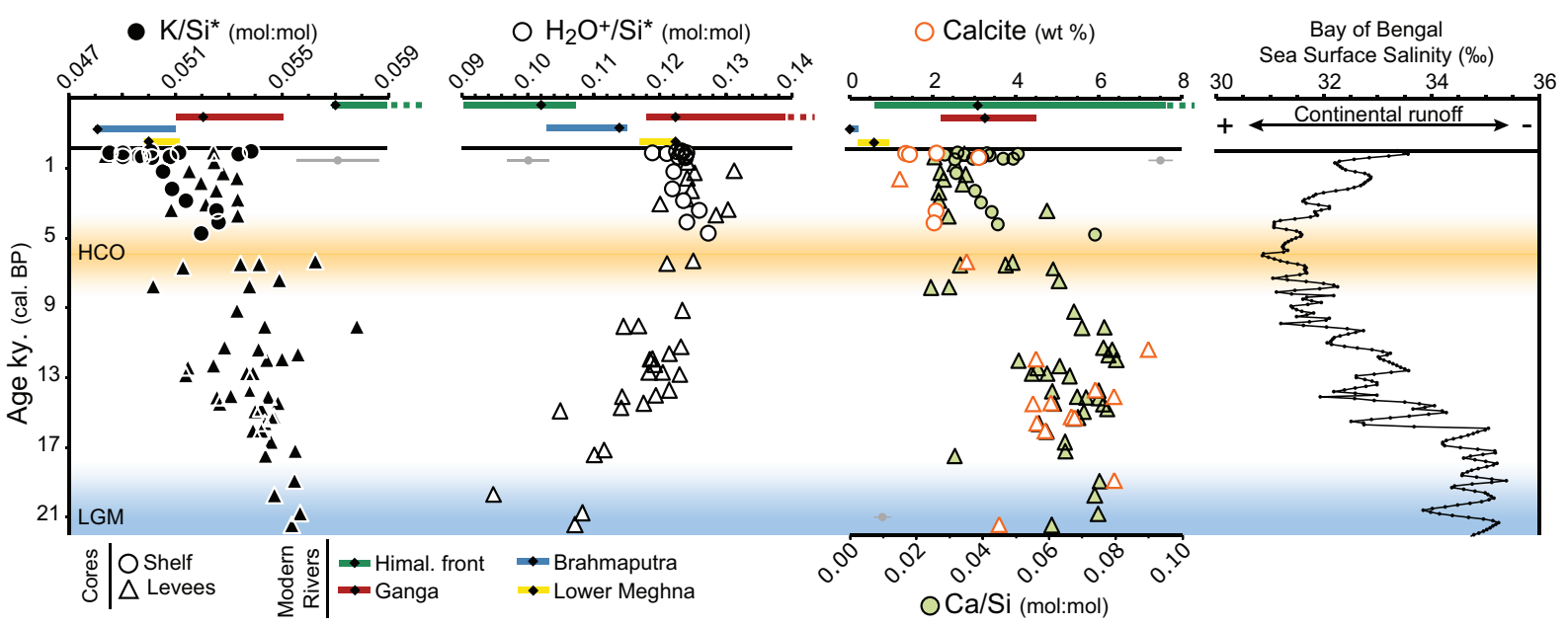

693 Figure 6: Evolution of $\mathrm{K} / \mathrm{Si}^{*}, \mathrm{H}_{2} \mathrm{O}^{+} / \mathrm{Si}^{*}, \mathrm{Ca} / \mathrm{Si}$ and calcite content of sediments in the composite Bay of Bengal record since the last ca. 21 kyr. The composition of river sediments from the modern Himalayan system (average and $1^{\text {st }}-3^{\text {rd }}$ quartile range) is also plotted for comparison with the sediment record. The Bay of Bengal sea surface salinity (Kudrass et al., 2001) is shown as a proxy for the Ganga \& Brahmaputra continental runoff. The average, $1 \sigma$ uncertainty on the elemental ratios is indicated by light grey horizontal error bars. 


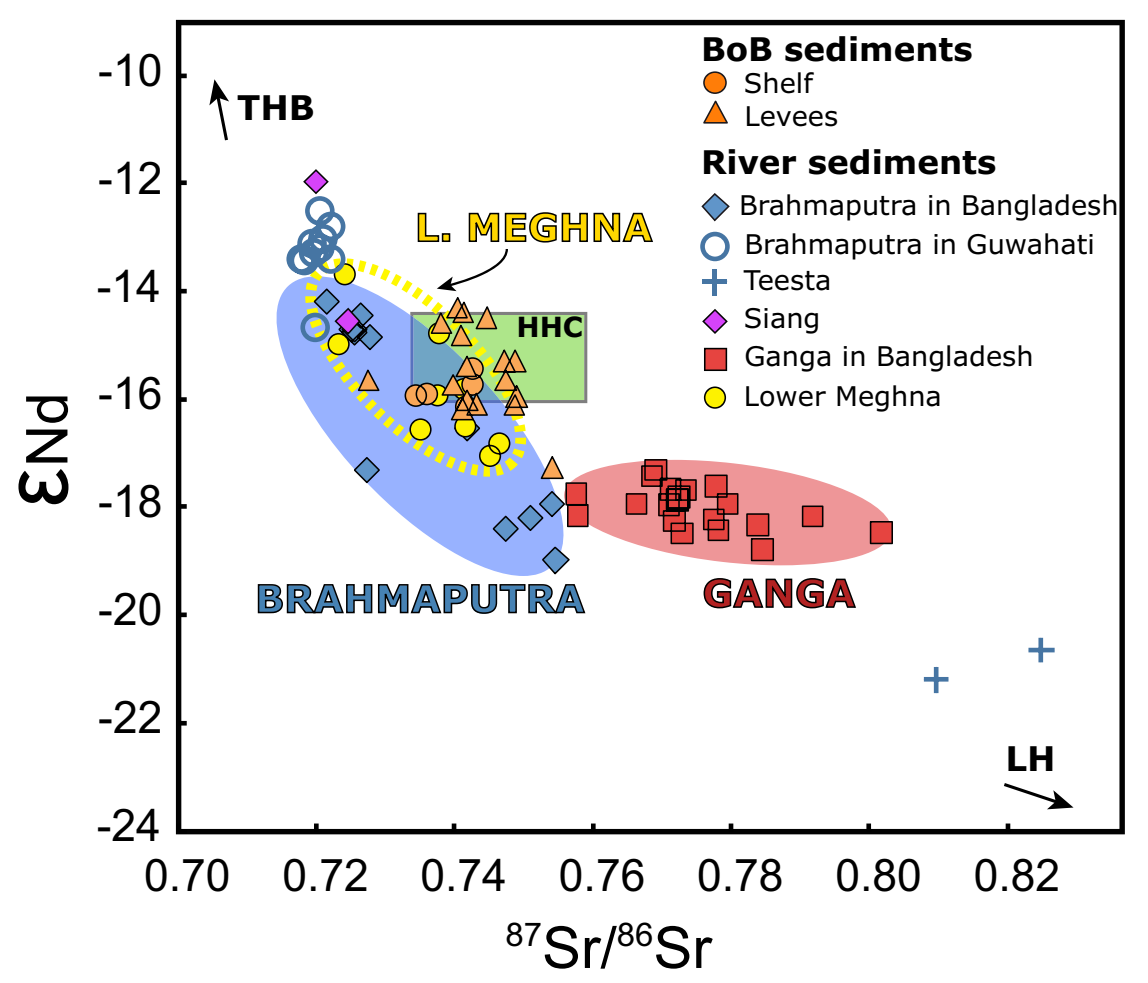

Figure 7: $\mathrm{Sr}$ and $\mathrm{Nd}$ isotopic composition of the sediments from the Bay of Bengal.

703 The modern river sediments of the Ganga in Bangladesh, the Brahmaputra in Bangladesh

704 (along with samples from the Siang, the Brahmaputra in Guwahati and the Teesta, Rivers

705 from Singh and France-Lanord, 2002) and the lower Meghna are represented for comparison.

706 The Sr and Nd isotopic data set of the Brahmaputra in Bangladesh has partly been acquired in

707 order to test sediment source effects in the Brahmaputra basin by selecting samples that

708 covered a large span of chemical compositions. This sample choice may have introduced a

709 bias towards samples that recorded a large input from the Teesta upstream right-bank

710 tributary. We therefore suspect the average $\mathrm{Sr}$ and $\mathrm{Nd}$ isotopic composition of the

711 Brahmaputra to be closer to the Brahmaputra in Guwahati and the Siang than our dataset

712 suggests (see supplementary information). The isotopic composition of the Lesser Himalaya

713 (LH), Higher Himalaya Cristalines (HHC) and Trans Himalayan Batholith (THB) are from

714 Galy and France-Lanord (2001) and references therein. 


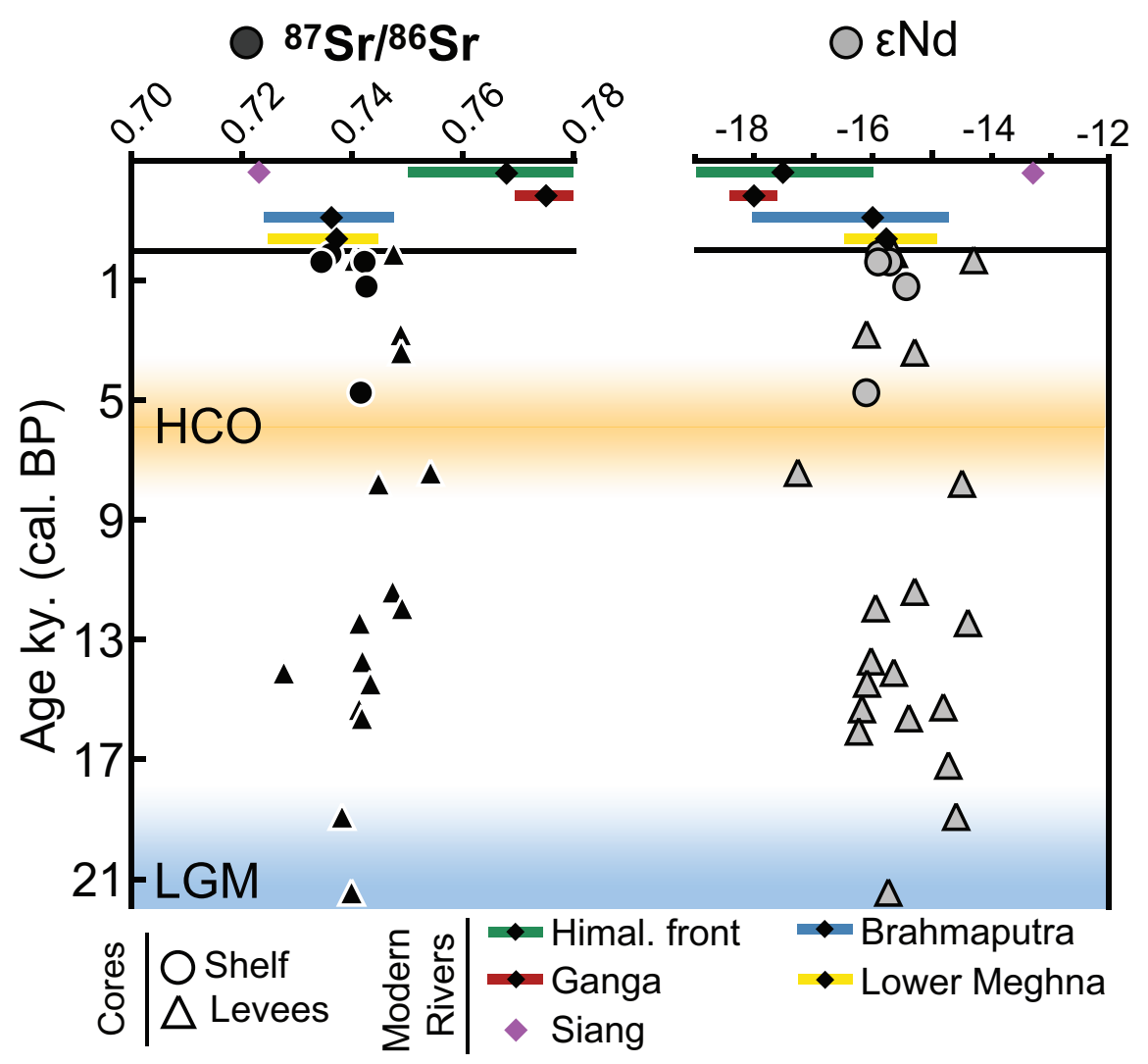

Figure 8: $\mathrm{Sr}$ and $\mathrm{Nd}$ isotopic composition of the silicate fraction of Bay of Bengal sediments (Pierson-Wickmann et al., 1998; Galy et al., 2008 and this study) along with the modern river sediments composition of the Himalayan front, the Ganga, the Brahmaputra and the lower Meghna (average and $1^{\text {st }}-3^{\text {rd }}$ quartile range). The isotopic composition of sediments from the modern Siang River (Singh and France-Lanord, $2002 \mathrm{~b}$ ) is also plotted. The Siang delivers ca. $50 \%$ of the sediment load of the Brahmaputra (Singh and France-Lanord, 2002b), contributing disproportionally to the final isotopic signature of the modern Brahmaputra. 


\begin{tabular}{|c|c|c|c|}
\hline & & LGM & Modern \\
\hline Sediment flux (t/yr) & & $1.10^{9}$ & $1.10^{9}$ \\
\hline \multirow[t]{2}{*}{ Himalayan front } & $\overline{K / S i *}$ & $0.0574( \pm 0.0025)$ & $0.0574( \pm 0.0025)$ \\
\hline & $\mathrm{H}_{2} \mathrm{O}^{+} / \mathrm{Si}^{*}$ & $0.1009( \pm 0.0068)$ & $0.1009( \pm 0.0068)$ \\
\hline \multirow[t]{4}{*}{ Bay of Bengal } & $\overline{K / S i} i^{*}$ & $0.0553( \pm 0.0005)$ & $0.0510( \pm 0.0017)$ \\
\hline & $\overline{\mathrm{H}_{2} \mathrm{O}^{+} / \mathrm{Si}^{*}}$ & $0.1034( \pm 0.0075)$ & $0.1236( \pm 0.0026)$ \\
\hline & $\mathbf{R} \boldsymbol{\phi}_{\mathrm{K}}$ & \multicolumn{2}{|c|}{$67( \pm 28) \%$} \\
\hline & $\mathbf{R} \phi_{\mathrm{H} 2 \mathrm{O}+}$ & \multicolumn{2}{|c|}{$89( \pm 36) \%$} \\
\hline
\end{tabular}

727 Table 1: Relative changes in the weathering flux delivered to the Bay of Bengal as dissolved load from the LGM to present $\left(\mathrm{R} \varphi_{\mathrm{K}}\right.$ and $\left.\mathrm{R} \varphi_{\mathrm{H} 2 \mathrm{O}^{+}}\right)$assuming a constant sediment flux over the period. The weathering flux was estimated using eq. 3 for $\mathrm{K}$ and $\mathrm{H}_{2} \mathrm{O}^{+}$from the Himalayan front and Bay of Bengal end-members reported in the table. 


\section{S1 - Chemical weathering proxies and data:}

The coarse grained end-members used to normalize the chemical composition of the Bay of Bengal sediments are reported in Table S1. This coarse-grained mixing end-member is determined as the intersection between the linear regression through the composition of Himalayan front sediments and the composition of sediments in Bangladesh (Ganga, Brahmaputra and lower Meghna) for $\mathrm{K} / \mathrm{Si}$ and $\mathrm{H}_{2} \mathrm{O}^{+} / \mathrm{Si}$. For Fe/Si (used in section S2), the common coarse-grained end-member composition is defined by the intersection between the regressions through Himalayan front sediments and southern and eastern tributary sediments (Chambal, Lohit and Dibang) as sediments from these rivers show a very contrasted $\mathrm{Fe} / \mathrm{Si}$ composition. This method was preferred over averaging all available bedloads as placer effects tend to introduce a very high variability in the chemical composition of the bedloads, which is not found in suspended load samples and therefore does not accurately describe the sediments that are mixed in the water column.

A summary of the composition of modern river sediments is reported in Table S2 and the composition of Bay of Bengal sediments in Table S3. The full, detailed data set of modern sediments and Bay of Bengal sediments is provided as electronic appendix.

\section{S2 - Sediment provenance:}

$751 \quad$ Sr \& Nd signature of Brahmaputra sediments:

It should be noted that the $\mathrm{Sr}$ and $\mathrm{Nd}$ isotopic data set of the Brahmaputra in

754 Bangladesh has partly been acquired in order to test sediment source effects in the 755 Brahmaputra basin by selecting samples that covered the largest span of chemical 
756 compositions. This sample choice introduces a bias towards samples impacted by the influx 757 from an upstream right-bank tributary, the Teesta, which has high $\varepsilon \mathrm{Nd}$ and $10 \mathrm{w}{ }^{87} \mathrm{Sr} /{ }^{86} \mathrm{Sr}$ 758 values (Figure 7). We therefore suspect the average $\mathrm{Sr}$ and $\mathrm{Nd}$ isotopic composition of the

759 Brahmaputra to be closer to that of the Brahmaputra in Guwahati (higher for Nd and lower for 760 Sr) than our whole dataset suggests.

The Sr and Nd isotopic composition of Brahmaputra sediments sampled at Guwahati, 762 upstream of the confluence with the Teesta show a homogeneous composition of $0.7201 \pm$ $763 \quad 0.0014{ }^{87} \mathrm{Sr} /{ }^{86} \mathrm{Sr}$ and $-13.3 \pm 0.7 \varepsilon \mathrm{Nd}$ (Figure 7, Singh and France-Lanord, 2002). These

764 sediments are mainly derived from the erosion of the Namche Barwa zone by the Siang River 765 that accounts for ca. $50 \%$ of the Brahmaputra sediment load (Singh and France-Lanord, 766 2002). The Teesta River has a contrasted isotopic composition due to the dominant exposure 767 of Lesser Himalayan rocks in the basin (Figure 7, Singh and France-Lanord, 2002) and its 768 confluence with the Brahmaputra mainstream is only ca. $120 \mathrm{~km}$ upstream of our sampling 769 station in Bangladesh. These considerations may also explain why the contribution of 770 Brahmaputra sediments to the lower Meghna is overestimated based on a simple $\mathrm{Sr}$ and $\mathrm{Nd}$ 771 isotopic budget of the Ganga, Brahmaputra and lower Meghna.

Increase in Southern or Eastern tributaries and Siwalik contribution since the LGM:

An increase in Siwalik derived sediments would generate a more weathered signature

776 of the Ganga \& Brahmaputra sediment load. Because Siwalik are Neogene floodplain 777 deposits produced by Himalayan erosion and uplifted by the southern propagation of the 778 deformation front, Siwalik sediments have a more weathered silicate signature but similar $\mathrm{Sr}$ 779 and $\mathrm{Nd}$ isotopic compositions than trans-Himalayan river sediments (Lupker et al., 2012). 780 However, the high carbonate content with lower $\delta^{13} \mathrm{C}$ compositions of Siwalik rocks and 
781 sediments (e.g. Sanyal et al., 2005; Lupker et al., 2012) is not compatible with the 782 concomitant decrease of both carbonate content and $\delta^{13} \mathrm{C}$ found in the Bay of Bengal 783 sediments (Figure S1).

Further changes in erosion patterns involving cratonic tributaries are also unlikely.

785 The Chambal River in the Ganga basin and the Eastern tributaries of the Brahmaputra basin 786 (Lohit and Dibang) have distinctively higher Fe/Si* ratios and unradiogenic $\mathrm{Sr}$ and $\mathrm{Nd}$ (Singh 787 et al., 2002; Singh et al., 2008; Lupker et al., 2012) signature that are not identified in our 788 record (Figure S1).

789

\section{S3 - Uncertainties and sensitivity of the weathering budget to the average Al/Si ratio:}

791

792

793

794

795

The analytical uncertainty from the major element and $\mathrm{H}_{2} \mathrm{O}^{+}$measurements is $2 \%$ on the $\mathrm{Al} / \mathrm{Si}$ and $\mathrm{Fe} / \mathrm{Si}$ ratios, $3 \%$ on the $\mathrm{K} / \mathrm{Si}$ and $\mathrm{H}_{2} \mathrm{O}^{+} / \mathrm{Si}$ ratios (Carignan et al., 2001). The uncertainty on the definition of the coarse grained end-member (Table S1) has only a minor effect on the normalized $\mathrm{K} / \mathrm{Si}^{*}$ and $\mathrm{H}_{2} \mathrm{O}^{+} / \mathrm{Si}^{*}$ ratios. For an average Bay of Bengal sediment sample with an $\mathrm{Al} / \mathrm{Si}$ ratio of 0.38 , the total uncertainty propagated from the analytical and normalization uncertainty is ca. $3 \%$ for the $\mathrm{K} / \mathrm{Si}^{*}, \mathrm{H}_{2} \mathrm{O}^{+} / \mathrm{Si}^{*}$ and $\mathrm{Fe} / \mathrm{Si}^{*}$ ratios on a $1 \sigma$ confidence level.

The sensitivity of the weathering budget to the average $\mathrm{Al} / \mathrm{si}$ ratio of the sediments is assessed by comparing $\mathrm{R} \varphi$ determined for an $\mathrm{Al} / \mathrm{Si}$ of 0.23 to $\mathrm{R} \varphi$ obtained using an $\mathrm{Al} / \mathrm{Si}$ of 0.21 and 0.25 (Table S4). This corresponds to ca. $10 \%$ of uncertainty on $\mathrm{Al} / \mathrm{Si}$ and is higher than the ca. 5\% uncertainty estimated by Lupker et al. (2011) for the average $\mathrm{Al} / \mathrm{Si}$ composition of sediments of the Ganga River but it takes into account the fact that in this case the average $\mathrm{Al} / \mathrm{Si}$ ratio of Brahmaputra sediments has not been determined directly. Table S4 shows that for the sensitivity of the weathering budget to the average $\mathrm{Al} / \mathrm{Si}$ is limited for a 
806 reasonable range of $\mathrm{Al} / \mathrm{Si}$ ratios. 
808 Supplementary information figures:

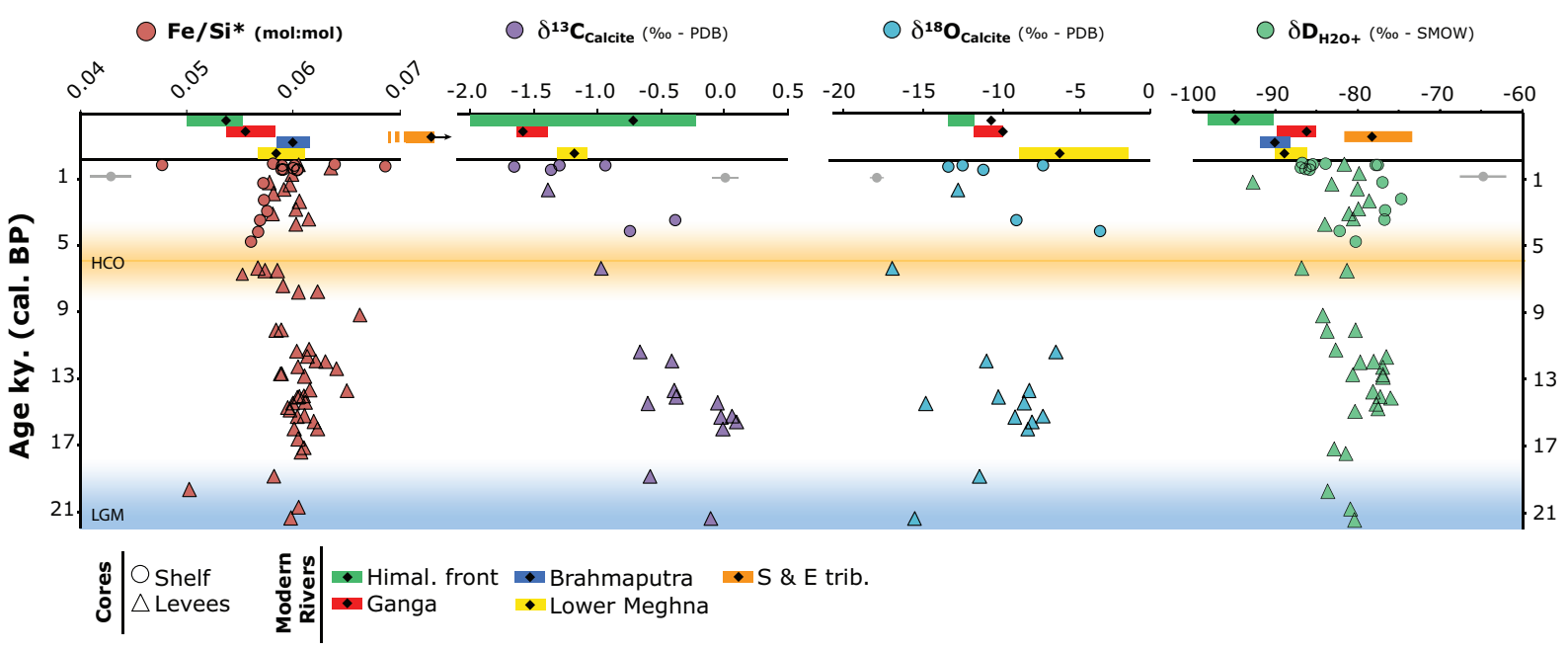

810 Figure S1: $\mathrm{Fe} / \mathrm{Si}^{*}, \delta^{13} \mathrm{C}_{\mathrm{PDB}}, \delta^{18} \mathrm{O}_{\mathrm{PDB}}$ of calcite and $\delta \mathrm{D}_{\mathrm{H} 2 \mathrm{O}}+$ in Bay of Bengal core samples and modern rivers (average and $1^{\text {st }}-3^{\text {rd }}$ quartile range). 
812 Supplementary information tables:

813

814

\begin{tabular}{|l|c|l|}
\hline \multirow{2}{*}{$/ \mathrm{Si}^{*}$} & $\mathrm{~K} / \mathrm{Si}$ & $0.029 \pm 0.001$ \\
& $\mathrm{Al} / \mathrm{Si}$ & $0.117 \pm 0.005$ \\
\hline \multirow{2}{*}{$\mathrm{H}_{2} \mathbf{O}^{+} / \mathrm{Si}^{*}$} & $\mathrm{H}_{2} \mathrm{O}^{+} / \mathrm{Si}$ & $0.060 \pm 0.002$ \\
& $\mathrm{Al} / \mathrm{Si}$ & $0.171 \pm 0.003$ \\
\hline \multirow{2}{*}{$\mathrm{Fe} / \mathrm{Si}^{*}$} & $\mathrm{Fe} / \mathrm{Si}$ & $0.020 \pm 0.003$ \\
& $\mathrm{Al} / \mathrm{Si}$ & $0.087 \pm 0.004$ \\
\hline
\end{tabular}

815 Table S1: Coarse-load mixing end-members used for the correction of hydraulic sorting 816 effects on the chemical composition of sediments. 
Table S2:

\begin{tabular}{|c|c|c|c|c|c|c|c|c|}
\hline & & $\begin{array}{c}\text { Ganga } \\
\text { Himalayan } \\
\text { Front }\end{array}$ & $\begin{array}{c}\text { Brahmaputra } \\
\text { Himalayan } \\
\text { Front } \\
\end{array}$ & $\begin{array}{c}\text { Himalayan } \\
\text { Front } \\
\text { Rivers }^{\mathrm{a}} \\
\end{array}$ & Ganga & $\begin{array}{l}\text { Brahm } \\
\text { aputra }\end{array}$ & $\begin{array}{l}\text { L. } \\
\text { Meghna }\end{array}$ & $\begin{array}{l}\text { S. and E. } \\
\text { tributaries }\end{array}$ \\
\hline \multirow{6}{*}{$\mathrm{K} / \mathrm{Si} *$} & Mean' & 0.063 & 0.054 & 0.057 & 0.052 & 0.048 & 0.050 & 0.036 \\
\hline & $\mathbf{s d}^{\mathbf{b}}$ & 0.001 & 0.004 & 0.002 & 0.001 & 0.001 & 0.001 & 0.007 \\
\hline & 1st $Q$ & 0.061 & 0.051 & 0.057 & 0.051 & 0.048 & 0.050 & 0.029 \\
\hline & Median & 0.062 & 0.055 & 0.061 & 0.054 & 0.049 & 0.050 & 0.039 \\
\hline & $\operatorname{3rd} \mathbf{Q}$ & 0.065 & 0.057 & 0.065 & 0.055 & 0.051 & 0.051 & 0.060 \\
\hline & $\mathbf{n}$ & 39 & 14 & 53 & 68 & 106 & 60 & 6 \\
\hline \multirow{6}{*}{$\begin{array}{l}\mathrm{H}_{2} \mathrm{O}^{+} / \\
\mathrm{Si} *\end{array}$} & Mean' & 0.099 & 0.102 & 0.101 & 0.122 & 0.114 & 0.122 & 0.065 \\
\hline & $\mathbf{s d}^{\mathbf{b}}$ & 0.003 & 0.011 & 0.007 & 0.005 & 0.003 & 0.002 & 0.004 \\
\hline & 1st $Q$ & 0.093 & 0.082 & 0.090 & 0.118 & 0.103 & 0.117 & 0.083 \\
\hline & Median & 0.099 & 0.089 & 0.098 & 0.127 & 0.112 & 0.119 & 0.118 \\
\hline & $\operatorname{3rd} Q$ & 0.109 & 0.104 & 0.107 & 0.142 & 0.115 & 0.122 & 0.159 \\
\hline & n & 32 & 12 & 44 & 26 & 26 & 21 & 4 \\
\hline \multirow{6}{*}{$\mathrm{Fe} / \mathrm{Si} *$} & Mean' & 0.052 & 0.055 & 0.054 & 0.056 & 0.060 & 0.059 & 0.082 \\
\hline & $\mathbf{s d}^{\mathbf{b}}$ & 0.001 & 0.004 & 0.003 & 0.001 & 0.007 & 0.002 & 0.012 \\
\hline & 1st $\mathbf{Q}$ & 0.050 & 0.052 & 0.050 & 0.054 & 0.059 & 0.057 & 0.077 \\
\hline & Median & 0.052 & 0.056 & 0.053 & 0.055 & 0.061 & 0.058 & 0.078 \\
\hline & 3rd Q & 0.054 & 0.061 & 0.055 & 0.058 & 0.062 & 0.061 & 0.096 \\
\hline & $\mathbf{n}$ & 39 & 14 & 53 & 68 & 106 & 60 & 6 \\
\hline \multirow{6}{*}{$\begin{array}{l}\text { Calcite } \\
\text { (wt\%) }\end{array}$} & Mean & 6.4 & 0.9 & 3.1 & 3.4 & - & 0.6 & 5.1 \\
\hline & sd & 6.0 & 1.1 & 2.5 & 1.3 & - & 0.8 & 3.1 \\
\hline & 1st $Q$ & 0.8 & 0.0 & 0.6 & 2.2 & - & 0.2 & 2.8 \\
\hline & Median & 4.0 & 0.1 & 3.1 & 3.9 & - & 0.2 & 4.9 \\
\hline & 3rd Q & 12.1 & 2.0 & 11.1 & 4.5 & - & 0.8 & 6.8 \\
\hline & $\mathbf{n}$ & 31 & 5 & 36 & 30 & - & 6 & 5 \\
\hline \multirow{6}{*}{$\begin{array}{l}\delta^{13} C_{\text {Calci }} \\
\text { te (\%o } \\
\text { - PDB) }\end{array}$} & Mean & -1.3 & -0.3 & -0.7 & -1.6 & - & -1.2 & -0.7 \\
\hline & sd & 1.2 & 0.8 & 0.7 & 0.4 & - & 0.1 & 1.6 \\
\hline & 1st $Q$ & -2.1 & -0.6 & -2.0 & -1.6 & - & -1.3 & -1.8 \\
\hline & Median & -1.2 & 0.0 & -1.2 & -1.5 & - & -1.2 & -1.5 \\
\hline & 3rd Q & -0.5 & 0.1 & -0.3 & -1.4 & - & -1.1 & 0.2 \\
\hline & $\mathbf{n}$ & 29 & 3 & 32 & 27 & - & 3 & 5 \\
\hline \multirow{6}{*}{$\begin{array}{l}\delta^{18} O_{\text {Calc }} \\
\text { ite (\%o } \\
\text { - PDB) }\end{array}$} & Mean & -12.3 & -9.4 & -10.6 & -10.0 & - & -6.2 & -6.8 \\
\hline & sd & 1.4 & 3.8 & 2.3 & 2.6 & - & 6.2 & 3.7 \\
\hline & 1st $Q$ & -13.2 & -11.6 & -13.2 & -11.6 & - & -8.4 & -9.8 \\
\hline & Median & -12.5 & -11.4 & -12.4 & -10.4 & - & -3.5 & -4.4 \\
\hline & 3rd Q & -12.2 & -8.2 & -11.7 & -10.0 & - & -2.6 & -4.4 \\
\hline & n & 29 & 3 & 32 & 27 & - & 3 & 5 \\
\hline \multirow{6}{*}{$\mathrm{Ca} / \mathrm{Si}$} & Mean & 0.115 & 0.027 & 0.062 & 0.058 & 0.042 & 0.043 & 0.115 \\
\hline & sd & 0.075 & 0.021 & 0.002 & 0.017 & 0.018 & 0.015 & 0.038 \\
\hline & 1st Q & 0.040 & 0.017 & 0.028 & 0.042 & 0.036 & 0.032 & 0.098 \\
\hline & Median & 0.104 & 0.018 & 0.064 & 0.063 & 0.040 & 0.039 & 0.108 \\
\hline & 3rd Q & 0.170 & 0.022 & 0.153 & 0.072 & 0.042 & 0.050 & 0.137 \\
\hline & $\mathbf{n}$ & 39 & 14 & 53 & 68 & 106 & 60 & 6 \\
\hline \multirow{6}{*}{$\begin{array}{l}{ }^{87} \mathrm{Sr} / /^{86} \\
\mathrm{Sr}\end{array}$} & Mean & 0.7713 & 0.7660 & 0.76813 & 0.77491 & 0.73562 & 0.73694 & 0.70705 \\
\hline & sd & 0.0101 & 0.0439 & 0.02665 & 0.01009 & 0.01271 & 0.00833 & - \\
\hline & 1st $Q$ & 0.7647 & 0.7329 & 0.74925 & 0.77111 & 0.72560 & 0.72547 & - \\
\hline & Median & 0.7726 & 0.7600 & 0.76440 & 0.77252 & 0.72779 & 0.73790 & - \\
\hline & 3rd Q & 0.7769 & 0.7870 & 0.77921 & 0.77825 & 0.74756 & 0.74157 & - \\
\hline & $\mathbf{n}$ & 8 & 11 & 19 & 21 & 13 & 9 & 2 \\
\hline \multirow{6}{*}{$\varepsilon N d$} & Mean & -18.9 & -16.6 & -17.5 & -18.0 & -16.2 & -15.8 & -9.7 \\
\hline & sd & 0.9 & 3.5 & 2.3 & 0.4 & 1.5 & 1.1 & - \\
\hline & 1st Q & -19.3 & -18.9 & -19.3 & -18.3 & -18.0 & -16.5 & - \\
\hline & Median & -18.8 & -16.0 & -18.2 & -18.0 & -16.0 & -15.9 & - \\
\hline & 3rd Q & -18.3 & -14.4 & -16.0 & -17.8 & -14.7 & -15.0 & - \\
\hline & $\mathbf{n}$ & 10 & 11 & 21 & 22 & 13 & 9 & 2 \\
\hline
\end{tabular}


820 Table S2: Averaged chemical composition of samples from the Himalayan system. The compositions are given separately for samples from the Ganga Himalayan front, the Brahmaputra Himalayan front, the average Himalayan front, the Ganga in Bangladesh, the Brahmaputra in Bangladesh, the lower Meghna (confluence of the Ganga \&

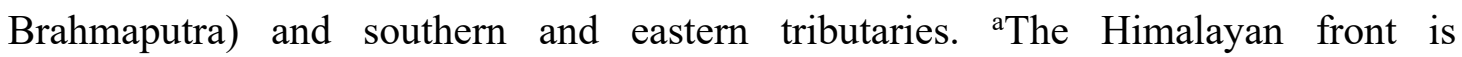
reconstructed assuming that $60 \%$ of the total sediment flux is generated by front rivers in the Brahmaputra basin and $40 \%$ by the front rivers in the Ganga basin. ${ }^{b}$ For element ratios affected by sediment sorting, the average and standard deviation of each end-member is constrained by evaluating the linear regression through the entire data set of each reach under consideration along with the coarse-grained end-member at $\mathrm{Al} / \mathrm{Si}=0.23$. The $1^{\text {st }}$ and $3^{\text {rd }}$ quartile, median and number of samples are also reported for all reaches. Detail on the chemical composition of samples used can be found in the electronic appendix. 
Table S3:

\begin{tabular}{|c|c|c|c|c|c|c|c|c|c|c|c|c|c|}
\hline Core & $\begin{array}{c}\text { Depth } \\
\text { cm }\end{array}$ & $\begin{array}{c}\text { Age } \\
\text { yr BP }\end{array}$ & $\begin{array}{l}\mathrm{Al} / \mathrm{Si} \\
\mathrm{mol}\end{array}$ & $\begin{array}{l}\mathrm{K} / \mathrm{Si}^{*} \\
\mathrm{~mol}\end{array}$ & $\begin{array}{c}\mathrm{H} 2 \mathrm{O} / \mathrm{Si}^{*} \\
\mathrm{~mol}\end{array}$ & $\begin{array}{c}\mathrm{Ca} / \mathrm{Si} \\
\mathrm{mol}\end{array}$ & $\begin{array}{c}\mathrm{Fe} / \mathrm{Si}^{*} \\
\mathrm{~mol}\end{array}$ & $d D$ & $\begin{array}{l}\text { Calci } \\
\text { wt\% }\end{array}$ & $d^{13} \mathrm{C}$ & $d^{18} O$ & $\begin{array}{c}{ }^{87} \mathrm{Sr} \\
\text { Sil }\end{array}$ & $\begin{array}{c}\text { eNd } \\
\text { Sil }\end{array}$ \\
\hline 105 & $77-86$ & 47 & 0.346 & 0.050 & 0.123 & 0.032 & 0.058 & -87 & & & & & \\
\hline 105 & 129 & 74 & 0.270 & 0.054 & 0.123 & 0.041 & 0.064 & -84 & & & & & \\
\hline 118 & $7-17$ & 98 & 0.401 & 0.052 & 0.123 & 0.032 & 0.060 & -82 & & & & 0.74740 & -15.7 \\
\hline 105 & 241 & 138 & 0.179 & 0.049 & 0.124 & 0.051 & 0.048 & -85 & 2.1 & -1.3 & -12.5 & 0.73600 & -15.9 \\
\hline 107 & $50-60$ & 147 & 0.391 & 0.051 & 0.124 & 0.034 & 0.059 & -78 & 1.4 & -0.9 & -7.5 & & \\
\hline 105 & 279-285 & 161 & 0.411 & 0.049 & 0.119 & 0.028 & 0.060 & -78 & & & & & \\
\hline 107 & 80 & 213 & 0.215 & 0.053 & 0.121 & 0.042 & 0.069 & -86 & 1.4 & -1.6 & -13.4 & & \\
\hline 118 & 29 & 313 & 0.405 & 0.048 & & 0.034 & 0.063 & & & & & 0.74040 & -14.3 \\
\hline 105 & $564-572$ & 325 & 0.335 & 0.050 & 0.124 & 0.040 & 0.060 & -87 & & & & & \\
\hline 105 & $664-670$ & 382 & 0.398 & 0.051 & & 0.037 & 0.060 & & & & & 0.74218 & -15.7 \\
\hline 105 & $678-685$ & 390 & 0.321 & 0.050 & 0.123 & 0.046 & 0.059 & -86 & & & & & \\
\hline 105 & $686-690$ & 394 & 0.192 & 0.049 & & 0.049 & 0.059 & & 3.1 & -1.3 & -11.2 & 0.73437 & -15.9 \\
\hline 105 & $758-765$ & 436 & 0.392 & 0.050 & 0.124 & 0.032 & 0.060 & -86 & & & & & \\
\hline 118 & $70-80$ & 681 & 0.385 & 0.052 & 0.124 & 0.025 & 0.060 & -80 & & & & & \\
\hline 120 & 53 & 1184 & 0.447 & 0.052 & 0.131 & 0.024 & 0.058 & -93 & & & & & \\
\hline 107 & $145-155$ & 1214 & 0.389 & 0.051 & 0.122 & 0.032 & 0.057 & -77 & & & & 0.74255 & -15.4 \\
\hline 118 & $134-145$ & 1302 & 0.393 & 0.053 & 0.125 & 0.032 & 0.060 & -83 & & & & & \\
\hline 118 & $165-175$ & 1603 & 0.400 & 0.053 & 0.124 & 0.035 & 0.059 & -80 & 1.2 & -1.4 & -12.8 & & \\
\hline 120 & 83 & 1854 & 0.412 & 0.052 & & 0.027 & 0.058 & & & & & & \\
\hline 107 & $210-220$ & 2212 & 0.412 & 0.051 & 0.122 & 0.038 & 0.057 & -75 & & & & & \\
\hline 118 & $220-230$ & 2317 & 0.385 & 0.053 & 0.125 & 0.028 & 0.060 & -79 & & & & & \\
\hline 118 & $265-275$ & 2799 & 0.385 & 0.053 & 0.124 & 0.027 & 0.060 & -80 & & & & 0.74872 & -16.1 \\
\hline 107 & $255-265$ & 2904 & 0.395 & 0.051 & 0.124 & 0.040 & 0.057 & -77 & & & & & \\
\hline 120 & 138 & 3083 & 0.378 & 0.052 & 0.120 & 0.034 & 0.058 & -81 & & & & & \\
\hline 120 & $147-157$ & 3396 & 0.411 & 0.051 & 0.130 & 0.103 & 0.061 & -80 & & & & 0.74879 & -15.3 \\
\hline 107 & 291-301 & 3457 & 0.376 & 0.053 & 0.126 & 0.043 & 0.057 & -77 & 2.1 & -0.4 & -9.1 & & \\
\hline 118 & $340-350$ & 3717 & 0.385 & 0.053 & 0.129 & 0.027 & 0.060 & -84 & & & & & \\
\hline 107 & $335-345$ & 4133 & 0.337 & 0.053 & 0.124 & 0.044 & 0.057 & -82 & 2.0 & -0.7 & -3.9 & & \\
\hline 107 & $376-385$ & 4748 & 0.362 & 0.052 & 0.127 & 0.074 & 0.056 & -80 & & & & 0.74153 & -16.1 \\
\hline 120 & 284 & 6345 & 0.304 & 0.056 & 0.125 & 0.059 & 0.057 & -87 & 2.8 & -1.0 & -16.9 & & \\
\hline 118 & $565-575$ & 6496 & 0.397 & 0.053 & 0.121 & 0.030 & 0.058 & -81 & & & & & \\
\hline 118 & 575 & 6496 & 0.390 & 0.054 & & 0.047 & 0.057 & & & & & & \\
\hline 118 & 656 & 6719 & 0.407 & 0.051 & & 0.033 & 0.055 & & & & & & \\
\hline 118 & 920 & 7418 & 0.298 & 0.055 & & 0.061 & 0.059 & & & & & 0.75414 & -17.3 \\
\hline 120 & 348 & 7775 & 0.461 & 0.050 & & 0.049 & 0.062 & & & & & 0.74467 & -14.5 \\
\hline 118 & 1144 & 7787 & 0.340 & 0.054 & & 0.063 & 0.060 & & & & & & \\
\hline 120 & 411 & 9182 & 0.422 & 0.053 & 0.123 & 0.030 & 0.066 & -84 & & & & & \\
\hline 117 & $242-257$ & 10070 & 0.372 & 0.054 & 0.117 & 0.082 & 0.059 & -80 & & & & & \\
\hline 120 & 452 & 10098 & 0.302 & 0.058 & 0.115 & 0.067 & 0.058 & -84 & & & & & \\
\hline 120 & 555 & 11255 & 0.412 & 0.053 & 0.123 & 0.070 & 0.061 & -83 & & & & & \\
\hline 120 & 579 & 11376 & 0.306 & 0.054 & & 0.076 & 0.060 & & 7.2 & -0.7 & -6.6 & 0.74723 & -15.3 \\
\hline 120 & $632-642$ & 11668 & 0.429 & 0.056 & 0.121 & 0.079 & 0.061 & -76 & & & & & \\
\hline 120 & $691-701$ & 11940 & 0.429 & 0.055 & 0.119 & 0.078 & 0.062 & -78 & 4.5 & -0.4 & -11.0 & 0.74899 & -16.0 \\
\hline 120 & 701 & 11991 & 0.418 & 0.054 & 0.119 & 0.080 & 0.063 & -80 & & & & & \\
\hline 120 & 762 & 12298 & 0.410 & 0.052 & 0.119 & 0.051 & 0.060 & -77 & & & & & \\
\hline 120 & 787 & 12424 & 0.322 & 0.051 & & 0.063 & 0.064 & & & & & 0.74129 & -14.4 \\
\hline 120 & 848 & 12731 & 0.370 & 0.054 & 0.118 & 0.056 & 0.059 & -77 & & & & & \\
\hline 120 & $845-855$ & 12736 & 0.364 & 0.054 & 0.120 & 0.059 & 0.059 & -81 & & & & & \\
\hline 120 & 863 & 12865 & 0.423 & 0.051 & 0.123 & 0.055 & 0.061 & -77 & & & & & \\
\hline 117 & $722-725$ & 13712 & 0.401 & 0.054 & & 0.077 & 0.061 & & 5.9 & -0.4 & -8.3 & 0.74180 & -16.0 \\
\hline 120 & $929-939$ & 13744 & 0.410 & 0.054 & 0.121 & 0.066 & 0.065 & -78 & & & & & \\
\hline 120 & 959 & 14053 & 0.412 & 0.053 & 0.119 & 0.061 & 0.061 & -77 & & & & & \\
\hline 117 & $772-774$ & 14096 & 0.400 & 0.054 & & 0.075 & 0.060 & & 6.4 & -0.4 & -10.2 & 0.72754 & -15.7 \\
\hline
\end{tabular}




\begin{tabular}{|c|c|c|c|c|c|c|c|c|c|c|c|c|c|}
\hline 120 & 965 & 14127 & 0.408 & 0.053 & 0.114 & 0.068 & 0.060 & -76 & & & & & \\
\hline 117 & 819-822 & 14457 & 0.416 & 0.055 & & 0.071 & 0.061 & & 4.9 & 0.0 & -8.6 & 0.74324 & -16.1 \\
\hline 120 & $990-1000$ & 14498 & 0.415 & 0.053 & 0.118 & 0.075 & 0.060 & -78 & 4.4 & -0.6 & -14.8 & & \\
\hline 120 & 1016 & 14758 & 0.388 & 0.054 & 0.114 & 0.076 & 0.059 & -77 & & & & & \\
\hline 120 & 1030 & 14931 & 0.409 & 0.054 & 0.105 & 0.077 & 0.060 & -80 & & & & & \\
\hline 117 & $922-925$ & 15249 & 0.400 & 0.055 & & 0.061 & 0.061 & & 5.3 & 0.1 & -7.4 & 0.74100 & -14.8 \\
\hline 117 & $930-932$ & 15310 & 0.421 & 0.055 & & 0.069 & 0.060 & & 5.4 & 0.0 & -9.2 & 0.74115 & -16.2 \\
\hline 117 & $970-972$ & 15610 & 0.391 & 0.054 & & 0.067 & 0.062 & & 4.5 & 0.1 & -8.1 & 0.74172 & -15.4 \\
\hline 117 & $1025-1029$ & 16048 & 0.408 & 0.054 & & 0.057 & 0.060 & & 4.7 & 0.0 & -8.4 & & -16.2 \\
\hline 117 & $1027-1029$ & 16056 & 0.407 & 0.054 & & 0.059 & 0.062 & & & & & & \\
\hline 117 & $1106-1109$ & 16663 & 0.408 & 0.055 & & 0.059 & 0.060 & & & & & & \\
\hline 117 & 1175 & 17185 & 0.402 & 0.056 & 0.112 & 0.065 & 0.061 & -83 & & & & & -14.7 \\
\hline 117 & $1209-1210$ & 17454 & 0.391 & 0.054 & 0.110 & 0.065 & 0.061 & -81 & & & & & \\
\hline 120 & 1114 & 18896 & 0.281 & 0.055 & & 0.075 & 0.058 & & 6.4 & -0.6 & -11.4 & 0.73811 & -14.6 \\
\hline 120 & 1127 & 19713 & 0.257 & 0.055 & 0.095 & 0.075 & 0.050 & -84 & & & & & \\
\hline 120 & 1104 & 20775 & 0.410 & 0.056 & 0.108 & 0.070 & 0.060 & -81 & & & & & \\
\hline 120 & $1130-1140$ & 21428 & 0.383 & 0.055 & 0.107 & 0.074 & 0.060 & -80 & 3.6 & -0.1 & -15.5 & 0.73980 & -15.7 \\
\hline
\end{tabular}

835 Table S3: Summary of the chemical composition of Bay of Bengal core samples used in this

836 work. Details can be found in the electronic appendix.

837 


\begin{tabular}{|c|c|c|c|c|}
\hline & & & LGM & Modern \\
\hline & Sediment flux (t/yr) & & $1.10^{9}$ & $1.10^{9}$ \\
\hline \multirow{6}{*}{$\begin{array}{l}\stackrel{m}{N} \\
0 \\
\text { II } \\
\text { in } \\
\frac{1}{4}\end{array}$} & \multirow{6}{*}{ Bay of Bengal } & $\overline{K / S i^{*}}$ & $0.0574( \pm 0.0025)$ & $0.0574( \pm 0.0025)$ \\
\hline & & $\overline{\mathrm{H}_{2} \mathrm{O}^{+} / \mathrm{Si}^{*}}$ & $0.1009( \pm 0.0068)$ & $0.1009( \pm 0.0068)$ \\
\hline & & $\overline{K / S i}{ }^{*}$ & $0.0553( \pm 0.0005)$ & $0.0510( \pm 0.0017)$ \\
\hline & & $\overline{\mathrm{H}_{2} \mathrm{O}^{+} / \mathrm{Si}^{*}}$ & $0.1034( \pm 0.0075)$ & $0.1236( \pm 0.0026)$ \\
\hline & & $\mathbf{R} \phi_{\mathrm{K}}$ & \multicolumn{2}{|c|}{$67( \pm 28) \%$} \\
\hline & & $\mathbf{R} \phi_{\mathrm{H} 2 \mathrm{O}+}$ & \multicolumn{2}{|c|}{$89( \pm 36) \%$} \\
\hline \multirow{6}{*}{ 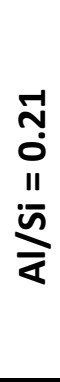 } & \multirow[t]{6}{*}{ Himalayan front } & $\overline{K / S i}{ }^{*}$ & $0.0524( \pm 0.0020)$ & $0.0524( \pm 0.0020)$ \\
\hline & & $\overline{\mathrm{H}_{2} \mathrm{O}^{+} / \mathrm{Si}^{*}}$ & $0.0871( \pm 0.0045)$ & $0.0871( \pm 0.0045)$ \\
\hline & & $\overline{K / S i}{ }^{*}$ & $0.0499( \pm 0.0004)$ & $0.0465( \pm 0.0014)$ \\
\hline & & $\overline{\mathrm{H}_{2} \mathrm{O}^{+} / \mathrm{Si}^{*}}$ & $0.0865( \pm 0.0046)$ & $0.0988( \pm 0.0016)$ \\
\hline & & $\mathbf{R} \boldsymbol{\phi}_{\mathrm{K}}$ & \multicolumn{2}{|c|}{$57( \pm 28) \%$} \\
\hline & & $\mathbf{R} \phi_{\mathrm{H} 2 \mathrm{O}+}$ & \multicolumn{2}{|c|}{$105( \pm 42) \%$} \\
\hline \multirow{6}{*}{$\begin{array}{l}\text { No } \\
0 \\
\text { II } \\
\tilde{j} \\
\dot{\alpha}\end{array}$} & \multirow[t]{6}{*}{ Himalayan front } & $\overline{K / S i}{ }^{*}$ & $0.0625( \pm 0.0029)$ & $0.0625( \pm 0.0029)$ \\
\hline & & $\overline{\mathrm{H}_{2} \mathrm{O}^{+} / \mathrm{Si}^{*}}$ & $0.1148( \pm 0.0091)$ & $0.1148( \pm 0.0091)$ \\
\hline & & $\overline{K / S i}{ }^{*}$ & $0.0606( \pm 0.0006)$ & $0.0555( \pm 0.0021)$ \\
\hline & & $\overline{\mathrm{H}_{2} \mathrm{O}^{+} / \mathrm{Si}^{*}}$ & $0.1203( \pm 0.0104)$ & $0.1484( \pm 0.0036)$ \\
\hline & & $\mathbf{R} \phi_{\kappa}$ & \multicolumn{2}{|c|}{$73( \pm 32) \%$} \\
\hline & & $\mathbf{R} \phi_{\mathrm{H} 2 \mathrm{O}+}$ & \multicolumn{2}{|c|}{$84( \pm 33) \%$} \\
\hline
\end{tabular}

839

840 Table S4: Relative change in weathering fluxes exported as dissolved load to the oceans obtained for $\mathrm{K}$ and $\mathrm{H}_{2} \mathrm{O}^{+}$using an average $\mathrm{Al} / \mathrm{Si}$ ratio of $0.23,0.21$ and 0.25 . The end members used for the calculation are also reported along with their uncertainty. 